Jutta SALminen

\title{
Epäily vai epäilys?
}

\section{Jaettu polysemia ja lekseemikohtaiset tyypilliset käytöt}

\section{Johdanto}

Kognitiivisen semantiikan lähtöoletuksena on, ettei täydellistä synonymiaa ole (Stanojević 2009, 193; Cruse 2000, 157-158; Evans 2009, 209-210; Päiviö 2007, 125). Hyvinkin lähimerkityksisille lekseemeille on siis odotuksenmukaista löytää kielen käytössä ainakin osittain eriytyneet tehtävät. Tästä näkökulmasta kiinnostavan lekseemiparin muodostavat teonnimijohdokset epäily ja epäilys, joiden merkitystyönjakoa selvitän tässä artikkelissa.

Epäilyn ja epäilyksen merkitystyönjaon tutkimista motivoi keskeisesti niiden kantaverbiltään perimä polaarinen kaksihahmotteisuus. Tämä tarkoittaa yksinkertaistaen sitä, että sekä epäillä-verbi että sen nominijohdokset voivat kontekstista - erityisesti täydennyksen syntaksista ja semantiikasta - riippuen tarkoittaa joko myöntöön tai kieltoon suuntautuvaa arviota: jos lääkärit epäilevät viinan suurkulutusta, he luultavasti pitävät sitä todennäköisenä, kun taas kansalainen, joka epäilee hallituksen kelvollisuutta, todennäköisesti kyseenalaistaa tämän (ks. Salminen 2017a). Erityisessä kontekstissa alkoholin suurkulutuksen epäileminen voitaisiin tulkita kuitenkin myös ehdottamani vastaisesti eli esitetyn suurkulutusväitteen kyseenalaistamisena. Polaariseksi kaksihahmotteisuudeksi kutsumani tulkinnan häilyvyys voi jopa aiheuttaa väärinymmärryksiä, mikä tekee kyseisen semanttisen ilmiön avaamisesta keskeistä. Koska tarkasteltavia nominivariantteja on kaksi, ne voisivat periaatteessa erikoistua jompaankumpaan tulkinnoista (ns. semeemikohtainen derivaatio; Koski 1981, 15), mikä olisi myös potentiaalisten väärinymmärrysten välttämisen näkökulmasta tarkoituksenmukaista. Käytännössä kuitenkin molemmat johdokset ovat perineet kyseisen polysemian (KS s. v. epäily, epäilys), joten lekseemien käyttökonteksteja täytyy tarkastella lähemmin mahdollisten erojen tunnistamiseksi.

Monet $-U$ ja $-U s$-johtimiset nominiparit erottaa toisistaan se, missä määrin niiden merkitykset ovat eriytyneet kantaverbistään (VISK 2004, \$ 234). Esimerkiksi johdospareissa ompelu(s) ja palvelu(s) s-päätteistä johdosta käytetään tyypillisesti yksittäisestä toiminnosta (palvelus), toimintokokonaisuudesta (esim. asepalvelus) tai toiminnan 
kohteesta/tuloksesta (ompelus), kun taas lyhemmät johdokset toimivat (myös) rajaamattomina teonniminä -minen-johdosten tapaan (KS s. v. ompelu, ompelus, palvelu, palvelus). Tämä havainto tarjoaa toisen lähtökohdan epäilyn ja epäilyksen lähimerkityksisyyden ja mahdollisten erojen tarkasteluun.

Artikkeli etenee seuraavasti: Johdantoluvun jäljellä olevassa osassa esittelen tutkimuksen teoriaa, aineiston ja metodit. Analyysi jakautuu yllä hahmoteltuihin kahteen päälinjaan: luvussa 2 tarkastelen johdosten merkitysten eriytymistä kantaverbistään epäillä ja tämän jälkeen luvussa 3 niiden polaarista kaksihahmotteisuutta. Luku 4 kokoaa analyysin keskeisimmät havainnot yhteen.

\subsection{Dynaamisen merkityksen polysemiasta ja synonymiasta}

Tutkimukseni viitekehys on kognitiivis-funktionaalinen: keskeisinä teoreettisina ja metodisina ohjenuorina ovat kielen ja merkityksen käyttöpohjaisuus ja dynaamisuus eli jatkuva liike ja muutos (ks. esim. Bybee 2010, 1-13; Langacker 1999, 91-145). Merkityksen dynaamisuudesta seuraa, että polysemia - tai laajemmin ei-monoseemisyys - on kielelliselle merkitykselle luontaista (Langacker 1999, 125; Raukko 1997, 146). Lisäksi polyseemisen sanan alamerkitykset voivat olla sumearajaisia (Tuggy 2006; Langacker 1999, 125-126). Tämä konkretisoituu epäily(kse)n polaarisen kaksihahmotteisuuden analyysissa siten, että edellä 'kelvollisuuden kyseenalaistamisen' ja 'suurkulutuksen todennäköisenä pitämisen' kautta esiteltyjen kahden vastakkaisen tulkinnan välille jää polaariselta suunnaltaan spesifioimattomia välitapauksia, eikä rajanveto näiden kolmenkaan ryhmän välillä ole aina ongelmatonta (ks. lukuja 3.1-3.2). Merkityskuvauksen haaste onkin usein se, kuinka dynaaminen merkitysnäkemys välittyy itse analyysiin, jonka yksiköt saattavat implikoida (ala)merkitysten staattisuutta ja tarkkarajaisuutta (Onikki 2000, 108-109; Raukko 1997, 147, 159-160). Käyttämääni polaarisen kaksihahmotteisuuden luokitteluun tuleekin suhtautua käytännön työvälineenä, joka mahdollistaa kahden lekseemin vertailun.

Tutkimusta motivoi siis havainto epäilyn ja epäilyksen merkitysten päällekkäisyydestä eli osittaisesta synonymiasta. Selvästi polyseemisten lekseemien synonymia on käytännössä polysemian jaettuutta: lähi- ja monimerkityksisyys kietoutuvat toisiinsa (Tola 2015, 182-183). Polysemian jakavien lekseemien mahdolliset merkityserot näkyvät siinä, että jotkin yhteisistä tulkinnoista ja konteksteista ovat toiselle lekseemille tyypillisempiä kuin toiselle (ks. Geeraerts 2006 [1988], 39). Artikkelin analyysi tähtää kokonaiskuvaan tällaisista epäilyn ja epäilyksen käyttöjen tyypillisyyksistä.

\subsection{Aineisto ja metodit}

Käyttöpohjainen ja dynaaminen merkitys varioi sekä konteksteittain että idiolekteittain, minkä vuoksi merkitysanalyysin perustaksi tarvitaan eri käyttökonteksteja ja useiden kielenkäyttäjien intuitioita heijastava aineisto. Tässä tutkimuksessa hyödynnän 8,05 milj. saneen HS.fi-uutiskommenttiaineistoa, joka sisältää Helsingin Sanomien verkkosivuston Kotimaa-osaston uutiset ja kolumnit sekä näihin kytkeytyvät lukijakommentit ajalta 
4.9.2011-5.9.2012. Uutisten vuoksi aineistossa korostuu epäilyn vakiintunut käyttö poliisitutkinnassa ja oikeusprosesseissa, mikä on otettava huomioon jakaumia tarkastellessa. Aineiston epäily(s)-esiintymistä valtaosa $(492 / 776)$ on kuitenkin lukijakommenteista, mikä mahdollistaa juuri sen tarkastelun, kuinka eri kielenkäyttäjät käyttävät tutkittavia lekseemejä. Artikkelin esimerkkien perään on merkitty, onko tekstikatkelma uutisesta (UUT) vai kommentista (комм).

Olen poiminut aineistosta kaikki lekseemien epäily $(\mathrm{N}=603)$ ja epäilys $(\mathrm{N}=173)$ esiintymät lähikoteksteineen. ${ }^{1}$ Keskustelun näkökulmien ymmärtämiseksi olen tarvittaessa tarkastellut laajempaa keskustelukontekstia (uutinen kaikkine kommentteineen). Taulukko 1 esittelee lekseemien syntaktiset konstruktiot ja niiden frekvenssit aineistossa. Jaottelu perustuu epäily(kse)n mahdolliseen täydennykseen, ${ }^{2}$ koska tämä on keskeinen polaarisen tulkinnan kannalta. Myös epäily(s)-loppuisten yhdyssanojen määriteosat toimivat vastaavassa funktiossa.

Taulukko 1. Epäily(s)-esiintymien täydennyskonstruktioiden määrät aineistossa.

\begin{tabular}{|l|l|l|l|l|}
\hline konstruktio & epäily $(\mathrm{n}=603)$ & $\%$ & epäilys $(\mathrm{n}=173)$ & $\%$ \\
\hline yhdyssana & 280 & 46 & 1 & 1 \\
\hline ei täydennystä & 215 & 36 & 56 & 32 \\
\hline elatiivitäydennys & 68 & 11 & 51 & 29 \\
\hline (että-)lause $^{*}$ & 27 & 4 & 47 & 27 \\
\hline muut (genetiivi, illatiivi, postpositiot) $^{* *}$ & 11 & 2 & 5 & 3 \\
\hline alisteinen kysymyslause $^{* *}$ & 2 & 0,3 & 13 & 8 \\
\hline
\end{tabular}

* Luku sisältää tukipronominilliset että-lauseet (epäily: 8, epäilys: 6; epäily siitä, että...), relatiivilauseen (epäily, jonka mukaan...) ja kaksi referatiivirakennetta (epäilys: 2; esim. epäilys sen tulleen julki...).

** Luku sisältää vain objektitulkintaisia genetiivejä (esim. huumeiden käytön epäily). Jos epäily(s) saa subjektitulkintaisen genetiivin, seuraa luokittelu epäily(kse)n objektitulkintaista täydennystä (esim. lä̈̈kärien epäily luulosairaudesta: elatiivitäydennys).

${ }^{* * \star}$ Luku sisältää tukipronominilliset täydennykset (esim. epäilys siitä, onko...; epäily: 1, epäilys: 3).

Huomiota herättävintä taulukossa on yhdyssanojen lähes yksinomainen epäily-loppuisuus sekä tämän konstruktion dominointi epäilyn esiintymissä (ks. lisää luvusta 3.3). Yhdyssanat ja ilman täydennystä esiintyvät sanat muodostavatkin epäily-esiintymistä jopa 82 prosenttia. Myös epäilys-sanaa käytetään paljon ilman täydennystä, mutta tällä

1 Epäily-lekseemin ylivoima aineistossa sekä joidenkin le-kantaisten Us-teonnimijohdosten arkaaisuus voi herättää ajatuksen epäilys-lekseemin vanhahtavuudesta (ks. VISK 2004, \$234; Nummila 2011, 57). Arvelun osoittaa kuitenkin perusteettomaksi katsaus tuoreeseen Suomi24-internetkeskusteluaineistoon (1.1.2001-24.9.2016), jossa epäilys-lekseemi (49 119 esiintymää) on epäilyä (46 699) yleisempi.

2 Nominit saavat lähtökohtaisesti määritteitä eivätkä täydennyksiä (kuten verbit), mutta verbin rektiotäydennyksiä vastaavia deverbaalinominin laajennuksia on perusteltua kutsua täydennyksiksi (VISK 2004, \$563). Ulotan periaatteen myös laajennuksiin, jotka eivät esiinny samansijaisina verbin kanssa: esim. elatiivilaajennus (epäily henkilön ahdistumisesta taakkaansa) vastaa funktioltaan verbin partitiiviobjektia (Vainikka 1992, 308-309). 
lekseemillä elatiivi- ja että-täydennykset kilpailevat aineistossa melko tasaisesti yleisimmän konstruktion paikasta.

Tutkimuksen merkitysanalyysi perustuu pääosin aineistoesiintymien manuaalisiin luokitteluihin sekä näiden määrällisiin vertailuihin ja laadulliseen tulkintaan. Keskeisimpiä analyysiluokkia ovat taulukossa 1 esiteltyjen täydennysvaihtoehtojen lisäksi polaarisen tulkinnan kategoriat (ks. lukuja 3.1-3.2), epäily(s)-sanan syntaktinen asema lauseessa sekä epäily(s)-esiintymän lähellä olevat kieltoelementit (ks. lukua 3.4). Kaikki luokittelut - myös luvussa 2 käsiteltävät kantaverbistä eriytymisen tavat - tähtäävät ensisijaisesti polaarisuuden vaihtelun syiden avaamiseen.

Manuaalisten luokittelujen lisäksi käytän epäilyn ja epäilyksen tyypillisten kollokaattien analyysissa ns. log-uskottavuusosamäärää (log-likelihood ratio; LLR), joka vertaa toisiinsa kollokaatin (kohdesana) esiintymistodennäköisyyttä koko aineistossa sekä tarkasteltavan lekseemin (noodin; epäily(s)) yhteydessä (ks. esim. Dunning 1993, 66). ${ }^{3}$ Juuri tyypilliset kollokaatiot erottavat usein lähimerkityksiset sanat toisistaan (Jantunen 2004, 8-10; Ivaska 2015, 19-20), ja LLR kertoo raakafrekvenssejä paremmin kollokaatioiden painoarvon: frekvenssiltään pienikin yhteisesiintymä voi olla aineiston kokonaisuudessa odotuksenmukaista suurempi ja siksi huomionarvoinen. Suhdeluvulla ei ole absoluuttista ylärajaa, joten sen osoittama painoarvo määrittyy aineiston sisäisesti: tässä aineistossa merkittävin yhden sanan etäisyyden kollokaatio herätä epäilys (LLR 351,86) on varsin huomattava (ks. lisää luku 2.2, esim. 3), kun seuraavaksi suurin LLR on 149,78 (pelkkä epäily; ks. luku 3.3, esim. 13). Aineistosta on laskettu LRR:t erikseen epäilyn ja epäilyksen etu- ja jälkikoteksteista sekä yhden että kolmen sanan etäisyydellä. Yhden sanan etäisyyden merkittävimmät etukollokaatit on taulukoitu liitteessä.

\section{Epäily(s)-johdosten semanttinen eriytyminen epäillä-verbistä}

Aloitan analyysin tarkastelemalla epäily(s)-nominien semanttista eriytymistä kantaverbistään. Tämän luvun havainnot toimivat pohjana seuraavan luvun polaarisen kaksihahmotteisuuden analyysille.

-U- ja -Us-johtimisten teonnimijohdosten merkitystä tarkastellaan usein suhteessa -minen-johdoksiin, jotka eroavat kantaverbinsä tulkinnasta vain siinä, että ne tiivistävät verbin kuvaaman prosessin abstraktin olion hahmoon (Leino 1993, 80; Möttönen 2016, 70-71; ks. myös Kangasmaa-Minn 1983, 24). ${ }^{4}$ Sen sijaan - $U$ - ja - Us-johdokset ovat eriytyneet enemmän kannastaan (Nuutinen 1976, 54; VISK 2004, \$ 224; Kangasmaa-Minn 1983, 28) - näin myös epäily ja epäilys. Ilmiötä kutsutaan usein leksikaalistumiseksi,

3 Kiitän Antti Kanneria teknisestä avusta analyysissa.

4 Käytän myös itse epäileminen-johdosta viittaamaan nominia vaativassa lauseasemassa epäilemistoimintaan enkä johdosta käyttäessäni pyri eksplikoimaan epäilemisen polaarista suuntaa.

5 Epäilyä käytetään tosin määräkonteksteissa -minen-johdoksen tapaan: filosofian termi metodinen epäily (ks. esim. Forsman 2012) ei yksilöi epäilemisen tilannetta tai toimijoita, vaan viittaa yleisiin tieteenteon periaatteisiin: 'että metodisesti epäillään'. 
mutta vältän termiä tässä yhteydessä, koska se viittaa myös kielenainesten leksikkoon vakiintumiseen ja tutkittavat lekseemit ovat kiistatta vakiintuneita (VISK 2004, \$224, 166; Kangasmaa-Minn 1983; Brinton-Traugott 2005, luku 2).

\subsection{Konteksteittain varioiva epäily(s)-nominin hahmo}

Avaan nominien merkityssuhdetta kantaverbiinsä kognitiivisen kieliopin profiloinnin käsitteen avulla: lekseemin profili eli hahmo on se asian tai käsitteen osa, jonka lekseemi nostaa huomion kohteeksi taustalle jäävästä kehyksestä eli laajemmasta käsitteestä tai tietorakenteista, joihin suhteessa lekseemin merkitys ymmärretään. Konkreettisena esimerkkinä hahmo/kehys-jaosta toimivat pinna ja vanne, jotka profiloivat eri hahmot samasta kehyksestä eli pyörän kokonaisuudesta. (Langacker 2008, 66-67.)

Abstraktin käsitteen hahmon analysointi on konkreettista tulkinnanvaraisempaa, mutta periaate on sama: mitä nomini nostaa ensisijaiseksi huomionkohteeksi? Kantaverbistään epäily(s)-nominit eroavat väistämättä jo sanaluokkansa vuoksi: kognitiivisen kieliopin termein verbi profiloi prosessin eli ajan etenemiseen suhteutuvan tilanteiden ketjun, kun taas nomini profiloi olion, jonka perustapaus on konkreettinen entiteetti (Langacker $1987 b, 54 ; 2008,106,112)$. Näin ollen verbin nominaalistuksen perusvaikutus on ilmauksen hahmon muuttuminen eritellystä prosessista holistisemmin hahmotetuksi olioksi (Langacker 1987b, 91). Merkitykseltään kiinteästi kantaverbiin kytkeytynyt deverbaali kuitenkin säilyttää osia prosessin käsitteellisestä rakenteesta ja voi profiloida myös vain jonkin osan siitä (Langacker 1987b, 90-91; 2008, 119-120, 346).

Sovellan profiloinnin käsitettä tässä yhteydessä siihen, kuinka tutkittavien lekseemien hahmot varioivat konteksteittain (ks. Möttönen 2016, 212; Geeraerts 2006 [1988], 46). Se, mitä epäily(kse)stä kulloinkin sanotaan, korostaa käsitteen eri puolia eli muovaa käytännössä nominin hahmoa (Langacker 1987b, 64; Kilgarriff 1997, luku 3.1; Cruse 1995, 34; 1986, 53). Epäily (kse) n mahdollisesti profiloimat käsitteen puolet voidaan jakaa asetelman 1 mukaisesti karkeasti kolmeen.

Asetelma 1. Epäily(s)-nominin hahmon mahdolliset osat.

a) mentaalinen toiminta eli itse epäileminen

b) se, mitä epäillään; monesti täydennyksessä ilmaistu asia(intila)

c) laajempia kulttuurisia tietokehyksiä

Vaihtoehdot eivät sulje toisiaan pois, eivätkä yksittäiset esiintymätkään ole aina yksiselitteisesti luokiteltavissa (Cruse 1995, 47-48). Tämän vuoksi käsittelen seuraavaksi hahmon variointia laadullisesti edustavien esimerkkien kautta - samalla kuitenkin aineistosta selvimmin esiin nousevia lekseemikohtaisia tendenssejä esitellen. 


\subsection{Hahmon raja(ama)tt(om)uus ja epäilemistoiminnan profilointi}

Käsittelen ensin epäilemistoiminnan profilointia (asetelma 1 a), joka yhdistyy ensinnäkin hahmon rajaamattomuuteen. Toisena tekijänä nousee esiin hahmon yhteys e-subjektiasemaan.

Rajattuuden ja rajaamattomuuden vastakohta hahmottuu selvimmin, kun verrataan luontaisesti rajattua eli jaotonta nominia, kuten (juoma)lasi, luontaisesti rajaamattomaan eli jaolliseen, kuten vesi (Langacker 1987b, 58, 91; Leino 1993, 78). Teonnimijohdosten tulkinta voi kuitenkin varioida (Langacker 1987a, 207), ja tätä vaihtelua havainnollistavat lähikotekstin vihjeet. Yksi rajattuuden merkki on käsitteen toistettavuus (Langacker 1987b, 66), joka näkyy muodon tasolla laskettavuutena (esim. 1) sekä monikkomuotona, jota käsittelen luvussa 3.2. (VISK 2004, \$225).

(1) [K]ymmenen hoitovirhe-epäilyä on erittäin paljon. Suurimmalla osalla ikäisistäni kollegoista tapauksia on joko nolla tai yksittäisiä. ${ }^{6}$ (комм)

Numeerinen määränilmaus (kymmenen) eksplikoi esimerkissä 1, että on kyse erillisistä rajatuista epäilytapauksista.

Siinä missä viittaus lukumäärään ohjaa rajattuun tulkintaan, synnyttää paljouskvanttori enemmän yksikön partitiivin kanssa rajaamattoman tulkinnan (Langacker 1987b, 66; Hakulinen-Karlsson 1979, 82; Leino 1993, 79). Tätä havainnollistaa seuraava esimerkki:

(2) On jo suuri erimielisyys siitä että tarvitaanko "ruuhkamaksua" niin vielä enemmän on epäilystä siitä, onko paikannukseen perustuva systeemi oikea. Paikannukseen perustuva systeemi kun on teknisesti epäluotettava ja ennenkaikkea jälleen kerran suuri uhka yksityiyydelle. (комм)

Esimerkin 2 epäilyksellä viitataan laajalti ilmenevään kyseenalaistavaan asenteeseen 'enemmän on sitä, että epäillään' eli eräänlaiseen ajattelun massaan. Rajaamattoman epäilyksen hahmossa on siis juuri epäilemistoiminta, jolloin nominin merkitys on vain vähän eriytynyt kantaverbistään (vrt. -minen-johdos; ks. VISK 2004, \$225).

Rajaamattomuuden lisäksi esimerkissä 2 on syytä kiinnittää huomiota epäilys-sanan syntaktiseen asemaan: se on e-subjektina intransitiivisessa kvanttorilauseessa, joka sanajärjestyksensä (verbi ennen epäilystä) vuoksi muistuttaa ilmiölausetta (VISK 2004, \$899, 902). Ilmiölauseilla kuvataan tyypillisesti alkavaa tai vallitsevaa tilannetta, tilaa tai tekoa, ja niissä verbi ja e-subjekti muodostavat usein idiomaattisen kiteymän, kuten syttyi sota tai ilmeni ongelmia (Vilkuna 1989, 165-166; VISK 2004, \$ 899). Epäilys-lekseemin vastaava kiteymä on herää epäilys, joka on myös yhden sanan etäisyydellä lasketuista koko aineiston vahvin kollokaatio (LLR 351,86).

6 Esimerkeissä epäily(kse)t on lihavoitu, täydennykset alleviivattu, täydennyksen tai epäily(s)-lekseemin korrelaatit katkoalleviivattu ja muut huomioitavat kielenelementit kursivoitu. Esimerkit ovat alkuperäisessä kieliasussaan mahdollisine lyönti- ja kirjoitusvirheineen aineiston autenttisuuden säilyttämiseksi. 
(3) Jos kaksi oikeusastetta on päätynyt toiselle kannalle kuin $\mathrm{KKO}$, niin herää epäilys, onko asia sittenkään ollut ihan niin yksioikoinen kuten uutisessa annetaan ymmärtää. (комм)

Herätä-verbin sisältävä ilmiölause kuvaa esimerkissä 3 epäilyksen alkuhetkeä, mikä aktivoi käsitteen ajallisen ulottuvuuden. Tämä sekä yllä kuvattu ilmiölauseen perussemantiikka ohjaavat (myös nominatiivisijaisen) nominin hahmon lähelle kantaverbin hahmoa eli epäilemistoimintaan: kun herää epäilys, epäileminen alkaa.

Esimerkeissä 2 ja 3 on molemmissa epäilys, ja e-subjektius onkin aineiston perusteella tyypillistä juuri tälle lekseemille: sen esiintymistä yli puolet $(56 \% ; 97 / 173)$ on e-subjekteja, kun niitä on epäily-esiintymistä vain $12 \%$ (74/603). Kun näistä vielä seulotaan e-lauseet, joilla on jokin ilmiölauseen piirre - keskeisimpinä tyhjä teemapaikka tai ilmiölauseelle ominainen verbi (esim. asiassa herää epäilys; minulle on herännyt mieleen epäilys) - on lekseemien välinen kontrasti vielä huomattavampi: näitä e-subjekteja on epäilys-esiintymistä $53 \%$ (92/173) ja epäily-esiintymistä vain 6\% (38/603). Toisin sanoen toimintahahmoon luontevasti erityisesti ilmiölausessa yhdistyvä e-subjektiasema on epäilys-lekseemin käyttöalaa. Sen sijaan epäily korostuu seuraavissa alaluvuissa käsiteltävissä rajatummissa hahmoissa.

\subsection{Propositiohahmo: se mitä epäillään}

Tarkastelen seuraavaksi esimerkkejä, joissa epäily(s) profiloi sen, mitä joku epäilee. Tällöin nominin hahmossa on propositio, joka voidaan myös eksplikoida epäily(kse)n täydennyksessä (asetelma 1 b). ${ }^{7}$ Nominin propositiohahmoiseen tulkintaan ohjaa esimerkiksi puhe epäily(kse)n totuudellisuudesta, koska propositiota voi arvioida juuri tästä näkökulmasta (Lyons 1977, 442-443; Leino 1991, 106; Larjavaara 2007, 216). Tätä havainnollistaa esimerkki 4, jossa kirjoittaja tiedustelee kysymyksellä ensin eksplikoimansa epäilyn todenperäisyyttä:

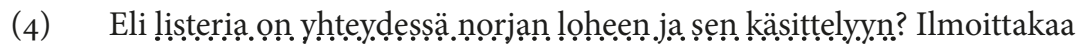
pitääkö epäilyni paikkansa ja kertokaa tarkasti missä kaikkialla se lohi kiertää eenen saapumistaan Suomeen. (комм)

Selvimmin pelkkään propositioon epäily(kse)n hahmo rajautuu silloin, kun joku kiistää toisen esittämän epäily(kse)n, kuten esimerkissä 5:

(5) VRLeaksin tekemässä tutkintapyynnössä epäillään yhtiön pitäneen yllä laitonta henkilörekisteriä sadoista ihmisistä. - - VR:n johto on kiistänyt kaikki epäilyt. (UUT)

7 Tarkalleen ottaen epäily(s)-lekseemin hahmoon on usein syytä lukea mukaan modaalisista aineksista riisutun proposition lisäksi lekseemin semantiikan virittämä epävarma propositionaalinen asenne, jota esimerkissä 4 havainnollistaa kysymysmuoto (ks. myös esim. 14 s. 233; ks. Larjavaara 2007, 427). 
Yhtiön johto ei luonnollisestikaan voi kiistämällä tehdä tai edes väittää olemattomaksi epäilijän eli esimerkin 5 tapauksessa tutkintapyynnön kirjoittajien mielenliikkeitä, minkä vuoksi kiistäminen kohdistuu nimenomaan epäilyn asiasisältöön eli propositioon. (Kiistämisestä ks. myös lukua 3.4.2.)

Propositiohahmoinen epäily(s) voidaan mieltää väljästi teon tuloksen (nomen acti) nimitykseksi (ks. Kangasmaa-Minn 1983, 27, 33): esimerkin 4 epäily ei olisi olemassa ilman kysyjän epäilemistä. Yleisesti ottaen epäilemistoiminta ja sen tulos eli epäilijän ajatus ovat kuitenkin siinä määrin samanaikaisia, että niitä on hankala ja tarpeetonkin erottaa toisistaan (ks. Kangasmaa-Minn 1983, 27). Onkin yleistä, että epäily(s) profiloi yhtä aikaa nämä molemmat (asetelma $1 \mathrm{a}+\mathrm{b}$ ). Näin tapahtuu esimerkiksi silloin, kun puhutaan epäilemisen perusteista:

(6) Vihreät ja Vasemmistoliitto ovat iskeneet haaskalle ja esittävät täysin perusteettomia syytöksiä ja epäilyjä. Kaivoksella [Talvivaara] on omat ongelmansa, mutta näiden puolueiden toiminta ei ole mitään muuta kuin oman kannatuksen nostattamista. (комм)

Esimerkissä 6 epäilyjä kutsutaan perusteettomiksi, jolloin tulkinta voi olla samanaikaisesti sekä 'se, mitä epäillään, on vailla perusteita' että 'epäillään ilman päteviä perusteita'. Myös puhe epäilyn sanallisesta julkituomisesta (esittävät) aktivoi sekä propositiohahmon että toimintahahmon: ensisijaisesti epäilyjen esittäminen lienee niiden kielentämistä (propositio), mutta samalla luonnollisesti sen julkituomista, että epäilee (toiminta).

Propositiohahmon aktivoivat todenmukaisuusarviot sekä sanallistamisilmaisut painottuvat aineistossa epäily-esiintymiin (esim. 4-6). Tämä havainto saa tukea kollokaattianalyysista: epäilyn etukollokaateissa kiistää on toiseksi vahvin (LLR 92,44) ja kymmenen vahvimman joukkoon mahtuvat myös ilmoittaa $(47,75)$, esittää $(36,05)$ ja tyrmätä $(30,37)$ (ks. liite). Monet kiistämistä vaativista epäilyistä ovat juridisia rikosepäilyjä tai sellaisiin verrattavia (ks. esim. 5), mihin käyttöön juuri epäily on vakiintunut. Kuitenkin myös epäilys-lekseemiä voidaan käyttää propositiohahmoisesti: aineistossa esim. pikainen googlaus vahvistaa epäilyksen (ks. tarkemmin esim. 14).

\subsection{Tapaushahmo: voiko kehys nousta profiliin?}

Hahmo/kehys-jaon edellä esiin tullut perusajatus on, että kielellisen ilmauksen hahmo "piirtyy" vasten taustalle jäävää kehystä. Kehys voi olla kompleksinen käsitteiden kokonaisuus ja sisältää myös kulttuurista tietoa tyypillisestä tapahtumienkulusta, kuten sanan ravintola virittämät kulttuuriset skriptit (Croft-Cruse 2004, 17; Schank-Abelson 1977, 42-46). Epäilyn kehykseen kuuluu erityisesti rikostutkintakontekstissa muun muassa perusteisiin, viranomaistoimenpiteisiin ja seurauksiin liittyvää tietoa. Perusmääritelmällisesti kaikki tämä on osa merkityksen kehystä, mutta esimerkiksi epäilyn konkreettisista vaikutuksista puhuttaessa epäily-sanan profiiliin nousee nähdäkseni joitakin näistä tietorakenteista. Havainnollistan ehdotustani seuraavalla esimerkillä ja nimitän kyseistä epäily-profiilia tapaushahmoksi: 
(7) Tänään haetaan ratkaisua Auto- ja kuljetusalan työntekijäliitto AKT:n johtajuuskiistoihin. Liiton valtuuston on määrä päättää siitä, miten kohua nostattanut rikosepäily työpaikkakiusaamisesta vaikuttaa puheenjohtaja Timo Rädyn (sd) asemaan. - - Liitto hyllytti maaliskuussa Rädyn tehtävistään viranomaiskäsittelyn ajaksi, koska häntä epäillään - -. (UUT)

Rikosepäilyn ilmaistaan esimerkissä 7 vaikuttavan (jollain tavalla) Rädyn asemaan. Koska pelkkä institutionaalinen epäileminen eli se, että epäillään (asetelma 1 a), ja rikosnimikkeessä tiivistetty propositio eli se, mitä epäillään (b), eivät vielä nähdäkseni epäillyn asemaa hetkauta, täytyy vaikuttaa-verbin subjektina olevan epäilyn hahmoon kuulua näiden lisäksi myös jotain esimerkiksi siitä, mitä tiedetään rikosepäilyn oikeudellisesta etenemisestä, sen saamasta julkisuudesta sekä näiden kytköksistä edellytyksiin toimia julkisessa tehtävässä (c). Tällaiset tietorakenteet kuuluvat normaalisti epäilyn kulttuuriseen kehykseen, mutta esimerkin 7 muotoilu epäily vaikuttaa ohjaa tulkitsemaan vähintään jotain tästä osaksi epäilyn hahmoa.

Tapaushahmoinen on myös edellä käsitelty hoitovirhe-epäily (esim. 1). ${ }^{8}$ Vaikka kyse ei ole (välttämättä) rikosepäilystä, profiloi se yhtä lailla laajan institutionaalisesti määritellyn olioidun toimintakokonaisuuden. Yhteistä esimerkeille 1 ja 7 on yhdyssanamuoto: Samalla kun yhdyssanan määriteosa (esim. rikos- tai hoitovirhe-) kuvailee epäilyn propositiosisältöä, toimii yhdyssana tietokehysten tiivistäjänä (Tyysteri 2015, 63). Aineiston yhdyssanat ovat yhtä poikkeusta lukuun ottamatta epäily-loppuisia (ks. taulukko 1), ja tämä on myös epäily-lekseemin frekventein konstruktio aineistossa. Tapaushahmoinen nomini on siis usein juuri epäily. Yhteensä 280:stä epäilyn yhdyssanaesiintymästä 123 on rikosepäilyjä, ja joukossa on myös täsmällisempiä nimikkeitä kuten raiskausepäily ja kavallusepäily.

Olen käsitellyt tässä luvussa sitä, millä eri tavoin epäily(kse)n osoittaman käsitteen hahmo voi rajautua. Aloitin epäilemistoiminnan profiloivista epäily(ks)istä (luku 2.2), jotka ovat merkitykseltään lähinnä epäillä-verbiä ja viihtyvät e-subjektiasemassa. Propositiohahmoiset epäily(kse)t (luku 2.3) ovat eriytyneet jo enemmän kantaverbin merkityksestä, sillä niiden profiilissa on se, mitä epäillään. Tapaushahmoinen epäily tiivistää hahmoon epäilemistoiminnan ja proposition lisäksi mahdollisesti myös kulttuurisia ja institutionaalisia tietokehyksiä. Kahta jälkimmäistä hahmoa havainnollistavissa esimerkeissä 4-7 epäily on aina perussubjektin tai objektin asemassa (ks. esim. 4-7). Näissä hahmoissa dominoivan epäily-lekseemin aineistoesiintymistä subjekteja tai objekteja onkin $44 \%$ (267/603), kun epäilys-esiintymistä niitä on vain neljännes ( $26 \%$; 45/173).

8 Tapaushahmosta voi metonyymisesti eriytyä myös henkilöviitteinen epäily (esim. syöpäepäily potilaasta, jolla epäillään olevan syöpä; KS s. v. epäily). Tällaisia ei kuitenkaan aineistossa esiinny tekstilajisyistä; sen sijaan potilaskertomuksissa näitä voisi esiintyä. (Langacker 2008, 69.) 


\section{Polaarinen kaksihahmotteisuus}

Etenen nyt epäily(s)-nominien polaarisen kaksihahmotteisuuden analyysiin, jonka edetessä kytken ilmiötä edellä käsiteltyyn epäily(kse)n hahmon variointiin. Esimerkkien lyhenteet viittaavat alaluvuissa 3.1 ja 3.2 avattaviin polaarisen tulkinnan analyysikategorioihin: S (sisältö), K (kohde) ja A (aihe/ambivalentti).

\subsection{Täydennysten funktiot ja epäily(s)-konstruktion polaarinen suunta}

Esittelin aineiston (ks. taulukkoa 1) epäily(kse)n täydennystyypin mukaan jaoteltuna, ja konstruktion polaarinen tulkinta perustuukin siihen, mikä kulloinkin on täydennyksen funktio suhteessa epäilemistoimintaan. Kun täydennys kielentää epäilijän ajatuksen tai sanat eli sen proposition tai asia(intila)n, joka epäilijän näkökulmasta on todennäköisesti totta tai olemassa, käytän siitä termiä sisältö. Seuraavien esimerkkien elatiivitäydennykset epäasiallisesta ammattitoiminnasta ( 8 a) sekä simputuksesta ja välinpitämättömyydestä (8 b) eksplikoivat tässä merkityksessä epäily(kse)n sisällön:

(8 a) Olemme ryhtyneet selvittämään yhtä epäilyä henkilön epäasiallisesta ammattitoiminnasta ja saaneet tietoa muutamasta muusta mahdollisesta tapauksesta. (UUT, S)

(8 b) Herää epäilys simputuksesta ja johdon välinpitämättömyydestä sille. (комм, S)

Sen sijaan täydennys, johon epäilijän kyseenalaistus kohdistuu, on epäily(kse)n kohde. Tällöin siis epäilijän oma ajatus on juuri vastakkainen. Elatiivisijainen täydennys voi toimia myös tässä funktiossa:

(9 a) Useilla mailla on epäilyjä palestiinalaisten yksipuolisen itsenäisyysjulistuksen hyödyllisyydestä Lähi-idän rauhalle, mutta vielä useammilla on epäilyjä Netanjahun vilpittömyydestä, kun hän vaatii palestiinalaisia takaisin neuvottelupöytään. (UUT, K)

(9 b) Toinen vanha totuus liene se, että asevelvollisuus tai talonpoikaisarmeija on aina luotettavampi kuin ammattiarmeija. Edellinen ei ehkä ole niin hyvä, mutta on luotettava ja puolustaa viimeiseen asti kotikontujaan. Jälkimminen on tehokas niin kauan kuin ọn.pạ!ḳạnmạạ̦̣ajạ ja jos siitä on epäilystä, ei puolenvaihtokaan ole kovin vaikeaa. (комм, K)

Esimerkissä 9 a kuvataan useiden maiden kyseenalaistavan hyödyllisyyden ja vilpittömyyden; samoin esimerkissä 9 b kyseenalaistetaan siitä-pronominin korrelaattina olevan lauseen on palkanmaksaja paikkansapitävyys. Analysoin tämän kyseenalaistuksen epävarmaksi kieltomerkitykseksi, joka juontuu etymologisesti epäillä-verbin kantana olevasta kieltoverbin partisiippimuodosta epä (SSA s. v. epäillä; Salminen 2017b, luku 1.2). Kieltäminen tai kyseenalaistaminen on reaktiivista (Verhagen 2005, 31-32; VISK 2004, \$1616), ja erityisesti esimerkki 9 b havainnollistaa, että epäily(kse)n kohde on ko(n)tekstissaan 
informaatiorakenteen näkökulmasta aktiivinen (Lambrecht 1994, 109): siitä viittaa edellä mainittuun ja epäilys reagoi tähän tunnistettavaan asiaan. Sen sijaan epäily(kse)n sisältö voi tuoda diskurssiin uuden asian: simputus on esimerkissä 8 b käsitteen ensimaininta kotekstissaan. (Ks. tarkemmin Salminen 2017a, 13-15.)

Esimerkkiparien välinen merkitysero on siis yksinkertaistaen siinä, tarkoitetaanko 'kyllä' vai 'ei'. Kyse ei kuitenkaan ole absoluuttisesta myöntö- tai kieltomerkityksestä, joten kutsun polaarisia tulkintoja myöntösuuntaiseksi (8) ja kieltosuuntaiseksi (9). Myöntö- ja kieltosuuntaisuus kuvaavat koko epäily(s)-konstruktion (sisältäen mahdollisen täydennyksen) polaarista tulkintaa, ja täydennyksen sisältö- tai kohderooli selittää, kuinka tämä luenta syntyy. Esimerkkien 8-9 perusteella tulkinta on sisältötäydennyksen kanssa myöntösuuntainen ja kohdetäydennyksen kanssa kieltosuuntainen: esimerkin 8 b epäilijän näkökulmasta simputusta (sisältö) on luultavasti tapahtunut, kun taas esimerkissä 9 b epäilyksellä ilmaistaan proposition 'on palkanmaksaja' (kohde) epävarmaa kieltoa. Kokonaiskuvaa kuitenkin mutkistavat täydennykset, jotka itse sisältävät eksplisiittisen tai implikoidun kiellon, sillä ne kielentävät selvästi epäilijän ajatuksen ja ovat siksi määritelmällisesti epäily(kse)n sisältöjä, mutta - tai juuri sen vuoksi - konstruktion kokonaistulkinta on kyseenalaistava eli kieltosuuntainen: esim. epäilys, ettei syytekynnys ole kaikkialla sama (ks. luku 3.4.1, esim. 17). Kyseenalaistus voi siis rakentua joko niin, että epäily(s) on siitä yksin vastuussa (kohdetäydennys; 9 a-b), tai niin, että tulkintaa rakentaa myös epäilijän ajatuksen eksplikoiva kielteinen sisältötäydennys. Käytän ensisijaisena analyysivälineenä täydennysten sisältö/kohde-jakoa, mutta tarkastelen kiellon sisältäviä täydennyksiä erikseen luvussa 3.4.1 kokonaiskuvan saavuttamiseksi.

\subsection{Arvottava kielteisyys ja polaarisesti ambivalentit epäily(kse)t}

Polaarisen suunnan ohella olennaista on, että epäily(s)-konstruktioilla ilmaistaan tyypillisesti jotain arvottavassa mielessä negatiivista. Kun katsotaan esimerkkejä 8-9, huomataan, että epäily(kse)n sisällöt (8 a-b) ovat järjestään negatiivisiksi eli esim. ei-toivottaviksi arvotettavia asioita (epäasiallinen ammattitoiminta, simputus, välinpitämättömyys), kun taas epäily(kse)n kohteet eli hyödyllisyys, vilpittömyys ja palkanmaksajan olemassaolo (esimerkissä 9 b korosteisesti juuri tekstistä hahmottuvasta palkkasoturin näkökulmasta käsin) saavat positiivisen arvon. Positiiviset asiat ovat esimerkeissä kuitenkin kyseenalaistuksen kohteina, joten epäily(s)-konstruktiolla ilmaistaan kaikissa tapauksissa jotain kontekstissa relevantista näkökulmasta arvottavasti negatiivista.

Nimityksestä polaarinen kaksihahmotteisuus huolimatta epäily(s)-esiintymät eivät jakaudu siististi kahteen luokkaan: välittömässä kotekstissa ei aina ole kielennettynä asia(intila)a, jonka voisi analysoida epäily(kse)n sisällöksi tai kohteeksi, mikä selventäisi polaarisen suunnan. Arvottava kielteisyys yhdistää kuitenkin myös vailla selkeää polaarista suuntaa olevat epäily(s)-konstruktiot edellä käsiteltyihin esimerkkeihin: 
(10) Pääsin kokeilemaan Sync-järjestelmää autovuokraamon Ford Focuksella. Odotukset olivat korkealla: tv-mainoksissa tyytyväinen omistaja kehuu vaihtaneensa Mersun ja Audin jälkeen Fordiin juuri Syncin takia. Pientä epäilyä herätti Microsoftin osallisuus projektissa. Yhtiöhän on erikoistunut tekemään melkein hyvää: melkein toimivia käyttöjärjestelmiä, jotka sopivat melkein yhteen kaikkien tietokoneiden kanssa. (комм, A)

Esimerkissä 10 kirjoittaja kertoo epäilystään, jonka ovat herättäneet puutteet yhtiön aiempien toimien laadussa (melkein hyvää). Epäilyn parafraasiksi sopisi yhtä hyvin niin jonkin ei-toivottavan ominaisuuden (esim. vikojen ilmaantumisen) todennäköiseksi arvelu kuin jonkin toivottavan (esim. järjestelmän kätevyyden) kyseenalaistaminen. Nämä molemmat kattava arvottavan kielteisyyden yläskeema riittää kuitenkin tarkoituksen ymmärtämiseen. Vastaavasti vastakkaiset merkitykset sulautuvat yhteen esimerkiksi englannin sanoissa sanction ja risk, joista erityisesti jälkimmäinen muistuttaa epäily(st)ä alamerkityksineen 'jonkin arvokkaan tai miellyttävän vaarantaminen' ja 'altistuminen jollekin epämiellyttävälle' (Kjellmer 2007; 1993). Tällaisten lekseemien tulkintaan liittyy lopulta näennäinen paradoksi: kun konteksti ei selvästi ohjaa kumpaankaan keskenään vastakkaisista tulkinnoista, merkityssekaannuksen sijaan nämä kaksi palautuvat yhteiseen yläskeemaan, joka on riittävä sekä tarkoituksen ilmaisuun että ymmärtämiseen (Kjellmer 1993, 120-121; Kilgarriff 1997).

Esimerkki 10 kuuluu väliluokkaan A, jossa ilmaukset ovat ambivalentteja polaarisen suunnan suhteen ja mahdollinen täydennys ilmaisee epäily(kse)n sisällön tai kohteen sijaan väljemmin sen aiheen (esim. 11 ja 12). Tällainen täydennys ei viittaa propositioon tai asiaintilaan, jonka todenmukaisuutta tai olemassaoloa voitaisiin arvioida, vaan se voi olla esimerkiksi konkreettinen entiteetti kuten kirja:

(11) [a] Minulla on ollut myös omat epäilyni Meinanderin kirjasta. [b] Nopealla vilkaisulla voi kuitenkin todeta, että Meinander ei näe ruotsissa Suomen tulevaisuutta. (комм, A)

Esimerkin 11 havainnollistaman aihetäydennyksen ero kohdetäydennyksiin on vain hienoinen: sen sijaan että täydennyksen olemassaolo tai totuudellisuus kyseenalaistettaisiin (vrt. esim. 9 a 'ei varmaan ole hyödyllinen/vilpitön'), kyseenalaistaa epäily(s) jonkin täydennyksen ominaisuuden arvottavan kielteisyyden merkityksessä. Esimerkin 11 katkelma on ruotsin opiskelua käsittelevästä keskustelusta, jossa on aiemmin kyseenalaistettu Meinanderin kyky kirjoittaa puolueettomasti Suomen kielellisistä oloista ruotsinkielisyytensä vuoksi. Vaikka siis ilmauksen omat epäilyni M:n kirjasta vaikuttaa ensikatsauksella epämääräiseltä (millaisia epäilyjä?), on se sitä vain näennäisesti myönnyttelevässä kontekstissa, jossa ensin osoitetaan samanmielisyyttä toisen keskustelijan esittämien näkemysten kanssa [a] ja sitten esitetään tälle kontrastiivinen havainto [b] (Niemi 2015, 14). Kirjoittajan epäilyt lienevät siis samansuuntaisia aiempien kyseenalaistusten kanssa. Epäilyn täydennys kielentää kuitenkin "vain" epäilyjen aiheen (vrt. epäily Meinanderin kirjan puolueettomuudesta, jossa täydennys olisi kohde). 
Täydennyksen ei kuitenkaan tarvitse viitata konkreettiseen entiteettiin saadakseen aihetulkinnan, mitä havainnollistaa esimerkki 12:

(12) Kiitos viestistäsi, se vahvisti epäilyni lääkäriopiskelijoiden motivaatiosta ja tavoitteista. Ei ihmisten hoitamisella ja auttamisella niin väliä, kunhan saa rahaa. (комм, A)

Koska esimerkissä täydennyksenä oleviin motivaatioon ja tavoitteisiin liittyy tyypillisesti positiivisia konnotaatioita, muistuttavat ne jo paljon edellä analysoituja kohdetäydennyksiä (ks. esim. 9 a-b). Ero kohderooliin on kuitenkin edelleen seuraava: kyse ei ole siitä, etteikö lääkäriopiskelijoilla olisi motivaatiota ja tavoitteita (vrt. esimerkin 9 a hyödyllisyys), vaan siitä, että niissä on kirjoittajan mielestä jotain vikaa. Kyseisen epäilyn sisältöä avaa katkelman viimeinen virke, jossa kirjoittaja eksplikoi näkemyksensä opiskelijoiden motiiveista. Esimerkit 9 a, 12 ja 11 havainnollistavat käytännössä jatkumoa eksplisiittisistä polaarisen kyseenalaistuksen kohteista aihetäydennyksen (hyödyllisyys, motivaatio, kirja) avulla pääteltäviin kohteisiin, mikä ilmentää epäily $(k s e) n$ polaarisen variaation sumearajaisuutta (ks. lukua 1.1).

Palaan vielä ajatukseen esimerkin 11 epäilyjen epämääräisyydestä. Huomion ansaitsee esimerkin epäilyjen monikkomuoto sekä monikon yleisyys aineistossa ylipäätään: epäilyesiintymistä yli puolet (304/603) on monikossa ja epäilys-esiintymistä noin viidennes (38/173). ${ }^{9}$ Monikkomuodon todettiin edellä yhdistyvän epäily(s)-käsitteen rajattuuteen ja epäilyn taaja esiintyminen monikossa antaa lisätukea sille, että rajatut propositio- ja tapaushahmot ovat tyypillisiä juuri epäily-lekseemille (ks. luvut 2.2-2.4). Tässä yhteydessä olennaista on kuitenkin myös, ettei monikon merkityspotentiaali rajaudu vain tarkkarajaiseen moneuteen, vaan sillä on lisäksi yhteys epämääräisyyden ilmaisuun sekä monenlaista affektista käyttöä (Yli-Vakkuri 1986, 62). Epäilyn monikko voidaankin esimerkissä 11 tulkita ennen kaikkea merkiksi epämääräisyydestä arvottavassa mielessä: spesifioimattomaksi arvottavaksi negatiivisuudeksi. Tämä tulkinta on nähdäkseni jopa luontevampi kuin epäilyjen useus.

\subsection{Polaarinen tulkinta lekseemeittäin ja täydennyskonstruktioittain}

Etenen nyt tarkastelemaan sitä, kuinka täydennysten funktiot ja polaariset tulkinnat jakautuvat aineistossa sekä lekseemeittäin että täydennyskonstruktioittain. Keskityn yleisimpiin konstruktioihin (yhdyssanat, täydennyksettömät, elatiivitäydennykselliset ja ettätäydennykselliset; ks. taulukko 1).

Kuvio 1 esittelee täydennyksen funktioiden (sisältö, ambivalentti/aihe, kohde; ks. luvut 3.1-3.2) jakaumat lekseemeittäin. Jakaumien merkitsevyyslaskelman perusteella lekseemivalinta vaikuttaa ilmauksen polaarista suuntaa ohjaavaan täydennyksen funktioon, ja nämä epäily- ja epäilys-konstruktioiden väliset erot ovat tilastollisesti erittäin

9 Kaikista HS.fi-aineiston substantiiveista noin neljännes on monikollisia. 


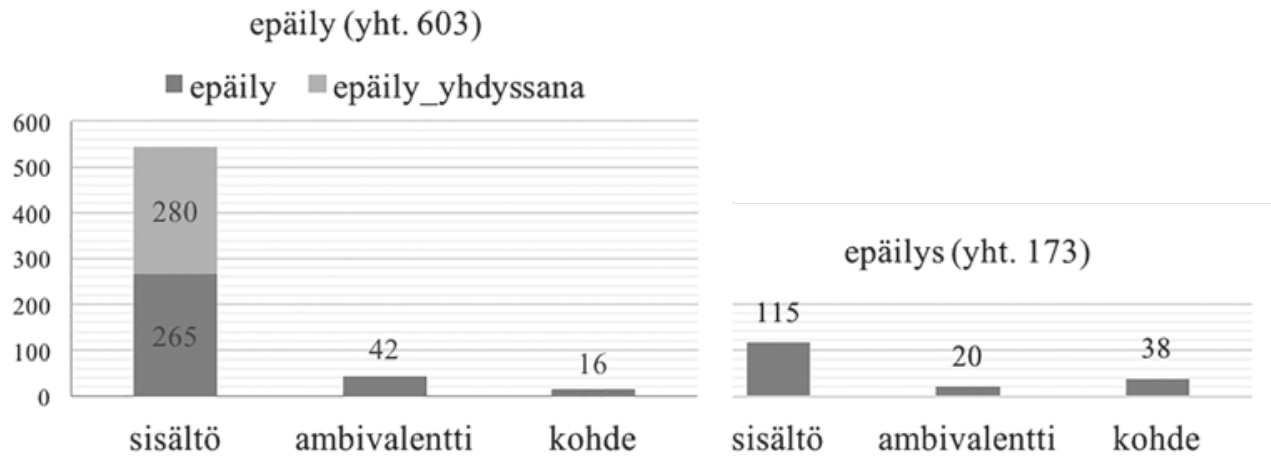

Kuvio 1. Epäily(s)-esiintymien täydennysten funktiot.

merkitseviä $\left(\chi^{2}=77.41 ; \mathrm{df}=2 ; p<0,001\right) \cdot{ }^{10}$

Kuvio 1 paljastaa välittömästi, että etenkin epäilyn esiintymissä täydennyksen sisältörooli hallitsee aineistossa. Myös epäilys saa useimmin sisältötäydennyksen (115/173; $66 \%$ ), mutta tällä lekseemillä tulkinta vaihtelee tasaisemmin. Suuren osan epäilyn ja sisältötäydennyksen symbioosista selittävät käytännössä poikkeuksetta epäily-loppuiset yhdyssanat. Yhdyssanan määriteosa kielentää aineistossa aina epäilyn sisällön: rikosepäily, home-epäily, lahjusepäily, susiepäily ja vuotoepäily tulkitaan kaikki siten, että määriteosan ilmaisema asia on luultavasti tapahtunut tai sitä esiintyy. Määriteosa voi kyllä periaatteessa ilmaista myös epäilyn kohteen, jos se kielentää positiivisen asian (esim. uskottavuusepäily), mutta tällaisia yhdyssanoja ei aineistostani löydy, mikä kertoo käytön harvinaisuudesta. ${ }^{11}$ Aineiston yleisin yhdyssana on rikosepäily (ks. lukua 2.4). Rikostutkintakontekstissa epäily-termin käyttö on vakiintunutta ja polaarisen tulkinnan analyysini termein oletuksena myöntösuuntaista 'rikos on ehkä/todennäköisesti tapahtunut', ja voidaan ajatella, että tämä frekventeimmän yhdyssanan oletustulkinta ohjaa myös muiden yhdyssanojen tulkintaa (ks. Ivaska 2015, 18 ja siinä mainitut lähteet).

Rikosepäilyjen vakiintunut polaarinen suunta selittää sisältöanalyysin yleisyyttä myös yhdyssanaryhmän ulkopuolella: täydennyksetön epäily viittaa aineistossa usein rikosoikeudelliseen epäilyyn, mikä puolestaan lukitsee polaarisen tulkinnan (ks. kuvio 2 ja esim.

10 Tilastollisen merkitsevyyden analyysissa käytetyn khiin neliö -testin taustaoletuksena on aineistoesiintymien keskinäinen riippumattomuus (Mäkisalo 2009, 58). Korpusaineistossa etenkin saman tekstin ja myös saman keskustelun sisällä yksittäisten esiintymien epäily(s)-lekseemivalinta ja polaarinen tulkinta voivat olla sekä samaviitteisyyden että kirjoittajan idiolektin vuoksi kuitenkin riippuvuussuhteessa keskenään. Merkitsevyyslaskelmiin on siis suhtauduttava pienellä varauksella, mutta suuntaa-antavina niitä voi pitää.

11 Kiitän artikkelin arvioijaa tulkinnan mahdollisuuden osoittamisesta. 


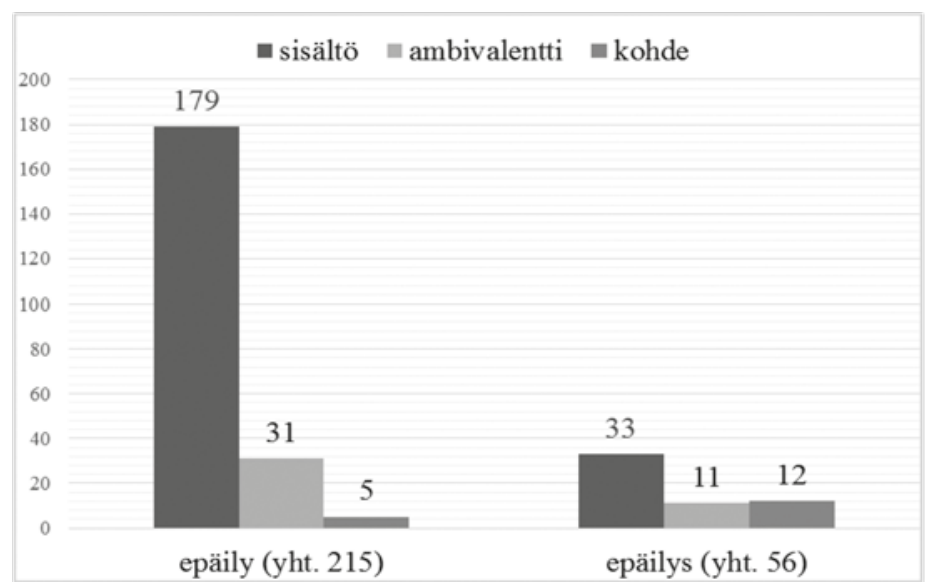

Kuvio 2. Implisiittisten täydennysten funktiot epäily(s)-lekseemeittäin. $\left(\chi^{2}=27.69 ; \mathrm{df}=2 ; p<0,001\right)$

13). Syntaktisen täydennyksen puuttuminen ei siis välttämättä johda esimerkin tulkitsemiseen polaarisesti ambivalentiksi (vrt. esim. 10). Implisiittisen sisältötulkintaisen täydennyksen saavista epäily-esiintymistä $84 \%$ (150/179) ja epäilys-esiintymistä $69 \%(22 / 33)$ esiintyy aineistossa selvästi rikostutkintaa käsittelevässä tekstiyhteydessä. Muita täydennyksettömien epäilyjen aihepiirejä ovat mm. sairaudet, terveyshaitat ja onnettomuudet, ja polaarinen tulkinta on myös näissä konteksteissa myöntösuuntainen: uumoillaan jonkin ei-toivotun olemassaoloa.

Täydennyksettömät epäilyt esiintyvät aineistossa usein keskusteluissa, joissa käsitellään itse (rikos)epäilyn käsitettä ja samalla oikeastaan epäily-lekseemin merkitystä: sen määritelmällistä epävarmuutta sekä leimaavuutta. Tälle mediakriittiselle diskurssille ominainen on esimerkin 13 havainnollistama epäilyn vahvin yhden sanan etäisyyden kollokaatio pelkkä epäily (LLR 149,78; ks. liite).

(13) Etpä taitaisi itsekään toivoa julkaisuja jos itse olisit epäiltynä jostain törkeästä teosta riippumatta siitä olisitko syyllinen vai ei. Jo pelkkä epäily saa valtaosan suomalaisita tuomitsemaan ihmiset. - - Ja tiedotusvälineet kyllä osaa julkaista asiat niin, että niistä saa vähintään väärän kuvan. (комм, S)

Esimerkin epäily viittaa mihin tahansa yksittäiseen rikosepäilytapaukseen. Se on siis referenssiltään geneerinen, mutta nominin hahmo on rajattu: epäilyn voi tulkita profiloivan joko tässä kontekstissa toki implisiittiseksi jäävän proposition (ks. luku 2.3) tai laajemmin koko rikosepäilytapauksen (ks. luku 2.4), eikä rajaa näiden välille tarvitse tehdä.

Täydennyksettömän epäily(kse)n polaarinen tulkinta voi tarkentua myös anaforan kautta. Esimerkissä 14 epäilys on samaviitteinen sen edeltävässä virkkeessä ilmaistun sisällön kanssa: 
(14) Juttu antaa ymmärtää, että lapsettomuushoidot olisivat raskaita siksi ettei ole totuttu vastoinkäymisiin. Lapsettomuushoitohan on yleensä hormonitai muuta lääkehoitoa, mistä tulee mieleen että ẹ̣kặ șe ọ̣ șe họ̣ițọ.

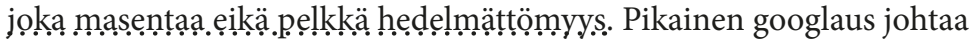
keskusteluun, joka vahvistaa epäilyksen. (комм, S)

Esimerkki 14 havainnollistaa myös edellä käsitellyn epäily(kse)n propositiohahmon ja täydennyksen sisältöluennan yhteyttä. Nämä kaksi eri suunnista (nominin hahmo ja polaarinen tulkinta) epäily(s)-lekseemien merkitystä lähestyvää analyysiyksikköä lankeavat käytännössä yhteen: kun nomini profiloi proposition - sen, mitä epäillään -, on tämä käytännössä samalla se epäilijän ajatus, jota kutsun polaarisuuden analyysissa epäily(kse)n sisällöksi. Esimerkissä 14 tämä propositiosisältö on 'hoito masentaa'.

Polaarisesti spesifioidut täydennyksettömät epäily(kse)t saavat siis polaarisen suuntansa joko diskurssikontekstin virittämän oletustulkinnan (13) tai anaforan (14) kautta. Yhdyssanat ja täydennyksettömät epäily-esiintymät muodostavat $82 \%$ epäilyn aineistoesiintymistä (ks. taulukko 1), ja näiden konstruktioiden tiuha esiintyminen rikostutkintakontekstissa selittää suurelta osin epäilyn (implisiittisen) täydennyksen sisältöanalyysin ja myöntösuuntaisen tulkinnan ylivoiman aineistossa.

Tutkittavien lekseemien keskinäisessä vertailussa epäilys näyttää olevan taipuvaisempi kieltosuuntaisuuteen: Epäilys-esiintymistä viidenneksellä (38/173, 22 \%) täydennys ilmaisee kyseenalaistuksen kohteen, kun epäily-esiintymillä kohdetäydennysten osuus on kokonaiskuvassa häviävän pieni (16/603, 3 \%; ks. kuvio 1). Noin puolet epäilys-sanojen kohdetäydennyksistä on elatiivissa, ja elatiivitäydennyksen rooli vaihtelee aineistossa kokonaisuudessaankin eniten (ks. kuvio 3; esimerkit 8-9).

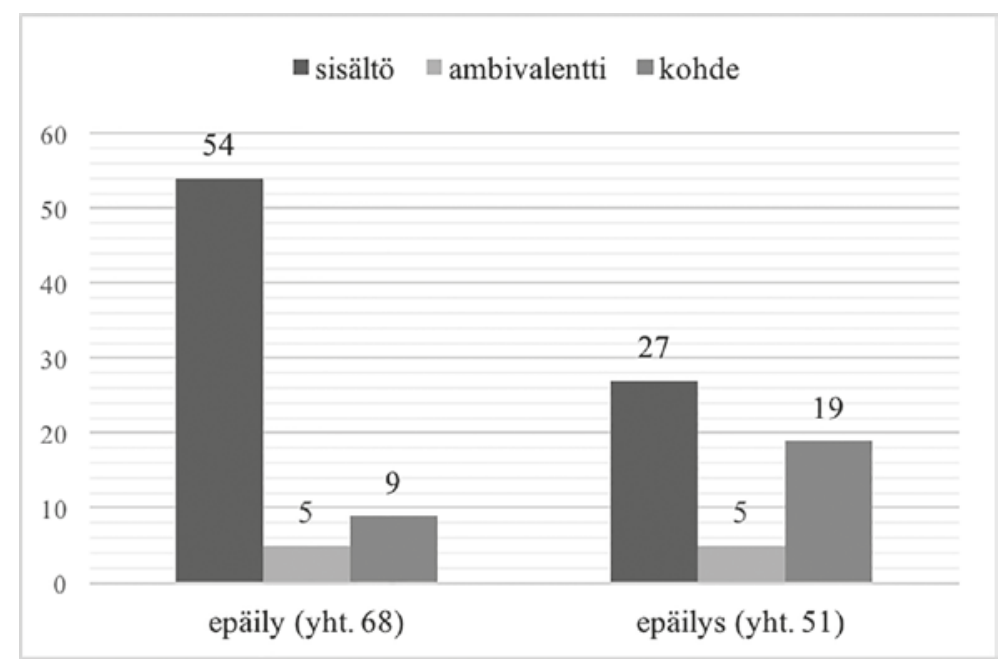

Kuvio 3. Elatiivitäydennysten funktiot epäily(s)-lekseemeittäin. 
Myös kuvion 3 havainnollistamassa elatiivikonstruktiossa erot epäilyn ja epäilyksen välillä ovat merkitseviä $\left(\chi^{2}=10.04 ; \mathrm{df}=2 ; \mathrm{p}<0,05\right)$ : kyseenalaistuksen kohteeksi tulkittava täydennys löytyy selvästi todennäköisemmin epäilys- kuin epäily-lekseemin jäljestä. Otan esimerkin tällaisesta käytöstä oikeuskontekstista:

(15) 4 syyttäjää on nimetty, jotta asia saadaan joutuisasti, riittävästi ja asianmukaisesti selvitettyä, jotta Auer joutuisi istumaan mahdollisimman vähän aikaa, mikäli tuomioistuin päättyy siihen tulokseen, että jää järkevä epäilys hänen syyllisyydestään tutkittavana oleviin rikoksiin. (комм, K)

Syyllisyys on esimerkissä 15 epäilyksellä ilmaistun kyseenalaistuksen kohde: todisteiden jäädessä riittämättömiksi on mahdollista, "ettei syyllisyys pidäkään paikkaansa" eli että syytetty onkin syytön. Selityksessä käyttämäni $-k A A n$ ja -kin -liitteet havainnollistavat, että kyseenalaistus reagoi institutionaalisen kontekstin tunnistettavaksi aktivoimaan syyllisyyden käsitteeseen (kohteen tunnistettavuudesta ks. myös esim. 9 b s. 227). Oikeusvaltiossa yksi keskeinen periaate on syyttömyysolettama (eli että vastaaja on syytön, kunnes toisin todistetaan), mistä seuraa pyrkimys välttää mahdollisimman pitkälle syyttömän tuomitsemista (Könönen 2006, 88). Tästä spesifistä näkökulmasta syyllisyys on tuomion antamisen hetkellä myös toivottava eli arvoltaan positiivinen asia, kuten epäily(kse)n kohteet aiemmissakin esimerkeissä.

Esimerkin 15 epäilys on e-subjekti, jossa lauseasemassa epäily(kse)n todettiin edellä (ks. lukua 2.2) profiloivan usein epäilemistoiminnan. Epäily(kse)n täydennyksen tulkinta kyseenalaistuksen kohteeksi edellyttääkin, että epäily(s) profiloi juuri kyseenalaistavan epäilemistoiminnan, joka reagoi täydennyksen totuudellisuuteen. Kohdetäydennys on siis lähtökohtaisesti erillinen siihen reagoivasta epäily(kse)stä. Sen sijaan sisältötäydennys eksplikoi epäily(kse)n mukaisen asiaintilan, minkä vuoksi esimerkiksi propositiohahmoista epäily(st)ä ei voi käsitteellisesti erottaa sen sisällöstä (epäilys = 'hoito masentaa', esim. 14).

On vielä huomautettava, että esimerkissä 15 muodossa jää järkevä epäilys syyllisyydestä ilmaistu todistelun käsite on 1.1.2016 voimaan tulleessa laissa oikeudenkäymiskaaren muuttamisesta vakiinnutettu muotoon jä̈ varteenotettava epäily syyllisyydestä (ks. 732/2015). ${ }^{12}$ Epäily-johdoksen käyttö on huomionarvoista, sillä tämän tutkimuksen aineiston valossa ilmauksen kyseenalaistavan tulkinnan edellyttämä täydennyksen kohderooli sekä sen kanssa luontevasti yhdistyvä ilmauksen ilmiölausesyntaksi ovat ominaisia nimenomaan epäilys-lekseemille.

Nostan viimeisenä esiin että-täydennysten tulkintatendenssin, joka seuraa epäilläverbin ja että-lauseen tyypillistä tulkintaa (ks. Salminen 2017a). Kaikissa epäily-esiintymissä (yht. 27) ja epäilys-esiintymissä neljää lukuun ottamatta (42/46) että-täydennys kielentää epäilemisen sisällön:

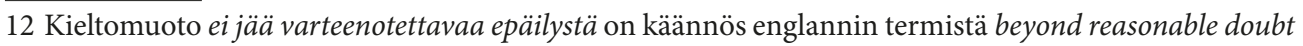
(ruots. utan rimligt tvivel) (HE 46/2014). 
(16) Tarkennus: rannalla ei ollut vaatekasaa, vaan vain laiturilla kauan lojuneet (kostuneet) kengät ja pieni laukku. Siitä syntyi epäilys, että henkilö olisi mennyt järveen ikävin aikein. Edelleen ihmettelen, missä ne vaatteet olivat - piilossa jossain vai päällä uidessa?! (комм, S)

Aiempien sisältötäydennyksellisten epäily(s)-esiintymien tapaan myös esimerkissä 16 täydennys kielentää epäilijän ajatuksen.

Kootusti voidaan todeta, että yleisimmät täydennyskonstruktiot seuraavat aineiston kokonaiskuvaa: täydennyksen sisältöfunktio on kaikissa konstruktioissa yleisin, mutta kieltosuuntaisuuteen johtava kohderooli on aina suhteellisesti yleisempi epäilyksen kuin epäilyn käytöissä. Tasaisimmin tulkinta varioi elatiivitäydennyksen kanssa. Kuitenkin myös sisältötäydennyksen kanssa epäily(s)-konstruktion kokonaistulkinta voi olla kieltosuuntainen, jos täydennykseen sisältyy kielto. Siirrynkin seuraavaksi tarkastelemaan aineiston kieltoelementtejä, minkä myötä kokonaiskuva aineiston epäily(s)-esiintymien polaarisuudesta täydentyy.

\subsection{Kieltoilmausten vaikutus epäily(s)-konstruktion polaariseen tulkintaan}

Olen välttänyt selkeyden vuoksi tähänastisissa esimerkeissä eksplisiittisiä kieltoelementtejä. Niitä esiintyy kuitenkin aineistossa taajaan, ja niillä on myös keskeinen rooli epäily(kse)n polaarisen tulkinnan muodostumisessa. Aloitan edellä ennakoiduista täydennyksen kielloista (esim. epäilys, ettei syytekynnys ole sama kaikkialla) ja etenen sitten epäily(s)-lekseemiin kohdistuviin kieltoihin (esim. ei ole epäilystäkään).

\subsubsection{Epäily(kse)n täydennysten kiellot}

Totesin yllä (ks. lukua 3.1), että epäily(s)-konstruktion kieltosuuntainen tulkinta voi syntyä joko yksin epäily(kse)stä (kohdetäydennys; esim. epäilys tarpeellisuudesta > 'ei ehkä tarpeellinen') tai siten, että sisältötäydennyksessä on kielto. Nyt havainnollistan tätä jälkimmäistä vaihtoehtoa, jonka perustapaus on että-täydennyksessä esiintyvä kieltoverbi:

(17) Apulaisvaltakunnansyyttäjä Jorma Kalske pitää Helsingin ja KantaHämeen syyttäjänvirastojen välistä eroa merkittävänä. Se herättää hänen mielestään epäilyksen, ettei syytekynnys ole sama kaikkialla. (UUT, S)

Esimerkin 17 epäilys-konstruktio kyseenalaistaa syytekynnysten yhdenmukaisuuden joka siis olisi epäilyksen kohde. Kyseenalaistus on kuitenkin eksplikoitu kieltolauseella, minkä vuoksi täydennys on analysoitu epäilyksen sisällöksi. HS.fi-aineiston kaikista ettälauseista kieltomuotoisia on noin viidennes (19\%), ${ }^{13}$ ja epäily $(k s e) n$ jälkeisistä 71 :stä jopa 20 (n. $28 \%$ ), kuten kuvio 4 osoittaa.

13 Laskelmassa että-lauseiden kokonaismäärä (106 883) on että-konjunktioiden frekvenssi aineistossa. Kielteisten että-lauseiden lukumäärä (20 767) on laskettu hakemalla sellaiset että-konjunktiota seuraavat kieltosanat, joissa konjunktion ja negaation väliin ei jää lauseen vaihtavaa konjunktiota tai välimerkkiä. Metodi ei ole toimittamatonta tekstiä sisältävässä aineistossa aukoton mutta suuntaa-antava. 


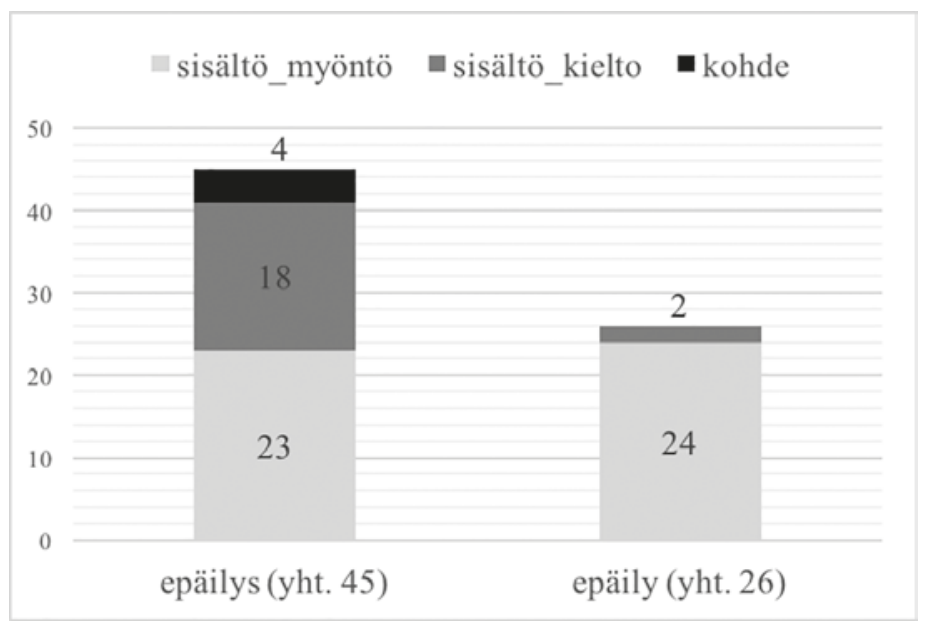

Kuvio 4. Että-täydennysten funktiot ja polaarisuudet.

Epäily(kse)n että-täydennykset kielentävät siis asiantiloja, jotka keskimääräistä useammin ilmaistaan kiellolla, mitä voisi kutsua kiellon projisoinniksi (projisoinnista ks. Auer 2005). Kuviosta 4 nähdään, että tämä tendenssi koskee etenkin epäilys-lekseemiä: aineiston kielteiset että-täydennykset ovat kahta lukuun ottamatta epäilys-esiintymien täydennyksiä.

\subsubsection{Epäily(s)-lekseemiin kohdistuvat kiellot}

Koska epäileminen on polaarisesti kaksihahmotteista, voidaan sen kieltokin tulkita kahdella tapaa: joko kyseenalaistamisen kieltämisenä (kumottu kieltosuuntainen) tai arvelemisen kieltämisenä (kumottu myöntösuuntainen):

(18) En epäile, että huomisaamuna olet jälleen terve ja voit jatkaa matkaa. ${ }^{14}$ ('en kyseenalaista' > 'voit varmaan jatkaa matkaa')

(19) Ay-liike ei epäile, että Lipposen hallituksella olisi jotain ylimääräistä hampaankolossa sitä vastaan. ('en arvele' > 'ei varmaan ole ylimääräistä hampaankolossa')

Kieltomuotoisella epäillä-verbillä kumottu kieltosuuntainen (esim. 18) tulkinta on kumottua myöntösuuntaista (esim. 19) yleisempi (KS s. v. epäillä; Salminen 2017a, luku 4.3). Epäilemiseen kohdistuva kielto siis usein ohjaa tulkitsemaan itse epäilemisen kieltosuuntaisena tai epävarmuutta ilmentävänä, jolloin koko ilmaus viestii vakuuttuneisuutta. Kiellon kohteena on se polaarinen tulkinta, mistä täytyy kyseisessä kontekstissa syystä tai toisesta sanoutua irti, ja monesti juuri kyseenalaistaminen on stigmatisoidumpaa. Tulkintamekanismi liittyy kiellon luontaiseen reaktiivisuuteen: kiellolla reagoidaan kontekstissa

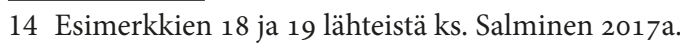


eksplisiittisesti tai implisiittisesti läsnä olevaan taustaoletukseen (Tottie 1991, 21, 27; Verhagen 2005, 31-32; VISK 2004, \$ 1616). Selvitän seuraavaksi, näkyykö sama kiellon ja kieltosuuntaisen tulkinnan kytkös myös epäily(s)-nominien käytöissä.

Käsittelen kieltoa semanttispainotteisesti rajautumatta pelkkään suomessa kieltoverbirakenteella ilmaistavaan lausekieltoon (ks. Miestamo 2004). Aineiston muita relevantteja kieltoilmauksia ovat inherentisti kielteiset ilmaukset (usein verbit) ${ }^{15}$ sekä adpositiot ilman ja vailla (VISK 2004, \$1626, 1628). Epäily(s)-konstruktion merkityksen näkökulmasta kiellot voidaan jakaa kolmeen ryhmään: propositiohahmoisen epäily $(k s e) n$ totuudellisuuden kieltoihin sekä tapaus- tai toimintahahmoisen epäily(kse)n olemassaolon kieltoihin.

Epäily(kse)n totuudellisuus kielletään usein inherenteillä kiellonilmauksilla, joista aineistossa yleisin $(\mathrm{n}=11)$ on jo edellä mainittu epäilyn vahva etukollokaattiverbi kiistää: VR:n johto kiistää kaikki epäilyt (ks. esim. 5). Kiistettävät epäilyt ovat poikkeuksetta propositiohahmoisia, jolloin mahdollinen täydennys on epäilyn sisältö. Polaarisuuden suhteen epäilyn kiistäminen edustaa siis kumottua (kiistää) myöntösuuntaista (epäilyt) tulkintaa: VR-esimerkin tapauksessa 'ei pidä paikkaansa että olisi pidetty yllä laitonta rekisteriä.

Epäily(kse)n olemassaolon kiellot kohdistuvat totuudellisuuden kieltoja suoremmin epäilemistoimintaan. Tällöin käytetään tyypillisesti kieltoverbiä tai kielteisiä adpositioita. Adpositiot ilman ja vailla ottavat luontaisesti täydennyksekseen ja samalla kiellon vaikutusalaan nominin (ilman epäilyä). Kieltoverbillä ilmaistu lausekielto kuitenkin kohdistuu nimensä mukaisesti lauseeseen ja sen fokuksessa on perustapauksessa lauseen reema (VISK 2004, \$ 1617), joten kaikki kieltoverbin esiintymät eivät ole analyysin kannalta relevantteja. Epäily(kse)n olemassaolo on kieltoverbillä ilmaistun kiellon kohteena vain silloin, kun epäily(s)-lekseemi on kielteisen eksistentiaalilauseen e-subjekti (lausetyypistä aineistossa ks. lukua 2.2). Tulkintaeroa muihin kiellon ja epäily(kse)n sisältäviin lauseisiin valottaa seuraava esimerkkisarja:

(20) Suomeen asti epäilyt eivät kantautuneet. (UUT, S)

(21) $[\mathrm{M}]$ yöhemmin esitettyä epäilyä / ilmiantoa ei tutkittu huolella ja loppuun asti. (Комм, S)

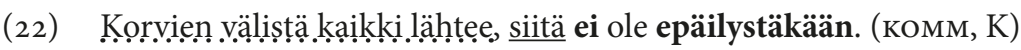

Esimerkin 20 epäily-subjekti on selvimmin kiellon vaikutusalan ulkopuolella. Tutkia-verbin objektina epäily jo kuuluu kiellon vaikutusalaan (esim. 21), mutta kieltämisen ensisijainen kohde on tutkiminen, ei epäily. Sen sijaan esimerkissä 22 e-subjektina oleva epäilys - merkityksen tasolla juuri sen olemassaolo - on kiellon kohteena.

Olemassaolon kiellot jakautuvat vielä kahtia lekseemin profiilin suhteen: on eri asia kieltää (rikos)epäilytapauksen (esim. 23) tai epäilemistoiminnan olemassaolo (esim. 22,

15 VISK (2004, \$1623-1633) ei käsittele inherentin kiellon kategoriaa kiellonilmaisukeinoissa, mikä ilmentää kategorian sumearajaisuutta (ks. myös van der Wurff 1998, 297-298). Tulkitsen inherentin kiellon sisältäviksi ilmaukset, joilla kuvataan epäily(kse)n totuudellisuuden (kiistää, tyrmätä, kumota, sanoutua irti) tai olemassaolon kieltoa (pois(taa), kitkeä, raueta, saada loppumaan). 
24 ja 25). Kun kiellon kohteena on tapaushahmoinen epäily, on kyse siitä, että institutionaalisesti määritellyn (rikos)epäilyn tunnusmerkit eivät täyty:

(23) Suomessahan tehdään puhalluskokeita valtavasti verrattuna muihin maihin. Joissain maissa niitä ei ilmeisesti edes saa tehdä ilman epäilyä rattijuoppoudesta. (комм, S)

Esimerkissä 23 kuvatun epäilyn täydennys (rattijuoppous) on rikostutkintakontekstin oletustulkinnan mukaisesti epäilyn sisältö ja polaarinen tulkinta ilman-kiellon kanssa kumottu myöntösuuntainen. Kun sen sijaan kielletään toimintahahmoinen epäily(s), kumottu kieltosuuntainen tulkinta nousee hallitsevaksi: esimerkin 22 lausekorrelaatillinen elatiivitäydennys on epäilys-sanalla ilmaistun kyseenalaistuksen kohde, ja kun tällaisen epäilyksen olemassaolo kielletään, viestii ilmaus kokonaisuutena varmuutta. Myös ilmanadpositiota käytetään tässä funktiossa:

(24) Täten käytännön elämässä on tietenkin hyväksyttävä joitakin kyseenalaistamattomia totuuksia, mutta mielestäni kyseenalaistaminen tulee asettaa paljon syvemmälle kuin siihen, että demokratia ja äänestäminen olisivat itsessään arvokkaita asioita, joihin voi luottaa ilman epäilyä ja jotka voidaan hyväksyä aksioomiksi keskustelussa yhteisten asioiden hoidossa. (комм, K)

Luottaminen ilman epäilyä tarkoittaa esimerkissä 24 varmuutta, sokeaa luottamista. Vaikka ilmaus siis muodon puolesta muistuttaa esimerkin 23 epäilyä, nominin profiilin ja polaarisen tulkinnan suhteen se on sukua esimerkille 22: ilman kieltää kyseenalaistavan epäilemistoiminnan.

Oletus kiellon ja epäily(s)-konstruktion kieltosuuntaisuuden yhteydestä toteutuu aineiston perusteella juuri toimintahahmoisen epäily(kse)n olemassaoloon kohdistuvissa kielloissa (esim. 22, 24 ja 25). Yhteys kantaverbille tyypilliseen tulkintamekanismiin on tällöin odotuksenmukainen, sillä toiminnan profiloiva epäily(s) on merkitykseltään lähinnä kantaverbiä 'että epäillään', 'että joku epäilee' (ks. lukua 2.2). Vastaavasti kumottu myöntösuuntainen tulkinta on täysin odotuksenmukainen sisältö- ja tapaushahmoisten (rikos)epäilyjen kielloissa ja kiistämisissä, koska tässä kontekstissa epäilyn polaarinen tulkinta on tyypillisesti myöntösuuntainen.

Totesin edellä että-täydennysten ilmaisevan tyypillisesti epäily(kse)n sisällön (ks. esim. 16 ja kuvio 4). Aineiston epäilys-esiintymistä löytyy kuitenkin muutama kohdeluentainen että-täydennys. Kaikissa näissä tapauksissa itse asiassa kielletään toimintahahmoisen epäilyksen olemassaolo, ja voidaan ajatella, että juuri tämä kielto aktivoi täydennyksen kohdetulkinnan:

(25) Saksan viranomaisten mukaan vakoilusta epäilty suomalainen Larsen eli Lassi Päivärinta toimitti DDR:lle 29 tutkimusraporttia vuosina 19821989. - - Stasi-arkiston tutkija Helmut Müller-Engbergs sanoo, ettei ole epäilystäkään, että Päivärinta on Larsen. Helsingin Sanomille Päivärinta on kiistänyt olleensa Stasin vakooja. (UUT, K) 
Että-täydennyksen propositio 'P. on L'. on epäilys-sanalla ilmaistun kyseenalaistuksen kohde, ja kun tämän epäilyksen olemassaolo kielletään, ilmaistaan sitoutumista propositioon. Rakenteen yhtäläisyyksistä huolimatta seuraavassa esimerkissä polaarinen tulkinta on päinvastainen:

(26) Lisäksi Valvira on pyytänyt paikkakuntien apteekeilta selvityksen siitä, miten ja kenelle Laiho on määrännyt lääkkeitä. "Kaikki mahdolliset asiat tutkitaan, myös väärinkäyttöön soveltuvien lääkkeiden suhteen vaikka ei ole epäilyä, että tapaus liittyisi vaikkapa huumausaineryhmiin kuuluvien lääkkeiden määräämiseen”, Henriksson sanoo. (UUT, S)

Esimerkin 26 epäilyn polaarista tulkintaa ei ohjaakaan siihen kohdistuva kielto, vaan rikostutkintakontekstin myöntösuuntainen oletustulkinta. Epäily voidaankin tulkita esimerkin 23 tapaan tapaushahmoiseksi: tällaista epäilyä ei ole vireillä. Myös konditionaalin (liittyisi) virittämä täydennyksen proposition non-faktuaalinen luenta sopii yhteen vain kumotun myöntösuuntaisuuden kanssa.

Epäily(s)-lekseemien työnjako esimerkeissä 25 ja 26 ansaitsee huomion: Rikoskontekstin esimerkissä on epäily, kun taas epäilemistoiminnan kieltävässä epäilys. Väitän, että lekseemien vaihtaminen päittäin vaikeuttaisi tarkoitettujen polaaristen suuntien ymmärtämistä. Väite saa myös laajempaa tukea aineistosta: kumotuksi kieltosuuntaiseksi tulkittavassa rakenteessa ei (ole) epäilystäkään (esim. 22 ja 25) on aina epäilys $(\mathrm{n}=10)$. Vaikka esiintymämäärä on vaatimaton, kytköksen keskeisyys saa jälleen tukea kieltoverbin ja epäilyksen kollokaation vahvuudesta: kolmen sanan etäisyydellä lasketuissa etukollokaateissa kieltoverbin ei LLR (ks. lukua 1.2) epäilys-lekseemin edellä $(55,15)$ on huomattavasti epäily-sanan vastaavaa $(0,08)$ korkeampi. Toisin sanoen kyseinen epävarmuuden tai kyseenalaistuksen kumoava fraasi näyttää vakiintuneen juuri epäilys-lekseemin sisältäväksi. Harvinaisempaa kumottua myöntösuuntaista tulkintaa (esim. 26) esiintyy taas lähinnä epäilyn käytöissä.

Luvussa 3.3 havaittu epäilys-konstruktioiden vahvempi taipumus täydennyksen kohdetulkintaan perustuu pitkälti esimerkkien 22 ja 25 havainnollistamaan kiellon ja kyseenalaistustulkinnan yhteyteen: 38 kohdetäydennyksellisestä epäilys-esiintymästä vain seitsemän ei ole minkäänlaisen kiellon kohteena. Epäilys-konstruktion kieltosuuntaisuus on siis lähes järjestään kumottua kieltosuuntaisuutta: ei ole epäilystäkään 'on varmaa'. Tämän luvun analyysi on nostanut muutoinkin esiin epäilys-lekseemin ja kieltoelementtien siteen: myös täydennysten kiellot kerääntyvät aineistossa juuri epäilyksen täydennyksiin (ks. 3.4.1).

\section{Koonti: epäilyn ja epäilyksen tyypilliset käytöt ja kontekstit}

Tämän tutkimuksen lähtökohtana oli havainto johdosten epäily ja epäilys merkitysten laajasta päällekkäisyydestä mutta myös oletettavasta epäidenttisyydestä. Analyysi onkin nostanut esiin lekseemien käyttöjä erottavia tekijöitä, ja kokoan nyt yhteen lekseemien 
keskeisimmät tyypillisyydet. On kuitenkin pidettävä mielessä, että yhden lekseemin tyypilliset tulkinnat ovat usein toisellekin lekseemille mahdollisia.

Epäilyn ja epäilyksen jaetun polysemian keskeisimpänä merkitysulottuvuutena on analysoitu arvottavaan kielteisyyteen kietoutuvaa polaarista kaksihahmotteisuutta: epäily(s)-konstruktiolla ilmaistaan jotain arvottavasti kielteistä joko jonkin positiivisen kyseenalaistamisen (kohdetäydennys) tai negatiivisen todennäköisenä pitämisen (sisältötäydennys) kautta - tai ilman selkeää polaarista suuntaa. Molemmilla lekseemeillä epäilijän ajatuksen eksplikoiva sisältötäydennys on aineistossa kohdetäydennystä yleisempi (ks. kuvio 1). Läpi analyysin nousi kuitenkin esiin epäilyksen vahvempi taipumus kyseenalaistukseen, ja tämän voi tiivistää kolmeen havaintoon: Ensinnäkin epäilys saa kaikissa täydennyskonstruktioissa epäilyä useammin kyseenalaistuksen kohteeksi tulkittavan täydennyksen (ks. esim. 9 b ja 15; kuviot 1-4). Toisekseen kieltomuotoiset täydennykset (epäilys, ettei...) ovat lähes yksinomaan epäilys-esiintymien täydennyksiä (ks. luku 3.4.1). Tällöin siis sisältötäydennys eksplikoi epäilijän kyseenalaistuksen. Kolmanneksi myös epäily(s)-lekseemiin kohdistuvat kiellot painottuvat epäilyksen esiintymiin (ks. luku 3.4.2), ja vakiintunut fraasi ei (ole) epäilystäkään ilmaisee juuri kyseenalaistuksen (tai epävarmuuden) kieltoa.

Juuri kiellon vaikutusalassa (ks. esim. 25 ei ole epäilystäkään, että P. on L. ja 26 ei ole epäilyä, että tapaus liittyisi...) erottuivat selvimmin seuraavat epäily(s)-lekseemien tyypilliset käytöt, joissa epäily(kse)n hahmon variointi (luku 2) yhdistyy polaariseen tulkintavariaatioon (luku 3): Epäilys-lekseemille epäilyä tyypillisempää on osittain rajaamaton epäilemistoiminnan profilointi (usein e-subjektiasemassa) sekä tämän lähellä epäillä-verbiä olevan hahmon mahdollistama reaktiivinen kohdetäydennyksen kyseenalaistaminen. Kun tällaiseen epäilemistoiminnan profiloivaan epäilykseen kohdistuu kielto, on lopputuloksena varmuutta viestivä kumottu kieltosuuntainen tulkinta (esim. 25). Epäily sen sijaan on taipuvainen (rikoskontekstin) propositio- tai tapaushahmoiseen rajattuun tulkintaan, jolloin konstruktio on polaariselta tulkinnaltaan myöntösuuntainen (täydennyksen sisältötulkinta). Kiellon vaikutusalassa lopputuloksena on tällöin kumottu myöntösuuntainen tulkinta; esimerkissä 26 epäilytapauksen olemassaolon kielto.

Jos nämä taipumukset abstrahoidaan koskemaan lekseemejä myös yleisemmin, sotivat ne sitä yleistystä vastaan, että - Us-johdos olisi - $U$-johdosta rajatumpi (ks. johdanto). Nähdäkseni ei ole kuitenkaan mielekästä yrittää määrittää epäilyn ja epäilyksen yleispätevää rajattuuseroa: Jos lekseemejä analysoi pelkän intuition varassa, voi epäilys tuntuakin yleistyksen mukaisesti yksittäiseltä ja epäily verbimäisemmältä ja rajaamattomalta (ks. myös alaviite 5 metodisesta epäilystä). Silti esimerkiksi juuri kiellon vaikutuksesta sekä rikostutkintakontekstissa luontaisesti rajatun epäily-termin vuoksi monissa aidoissa käyttökonteksteissa tendenssi on päinvastainen.

Keskeisimmäksi jatkotutkimussuunnaksi analyysi avaa rikosoikeudenkäyntien todistelutermin (ei jää) varteenotettava(a) epäily(ä) vakiintumisen ja ymmärrettävyyden, sillä tämän tutkimuksen valossa lekseemi epäilys olisi termin syntaktisessa ja semanttisessa kontekstissa johdospariaan odotuksenmukaisempi. 


\section{Lähteet}

\section{Aineistolähteet}

Aller Media Oy (2014). Suomi 24 virkkeet -korpus (2016H2) [tekstikorpus]. Kielipankki. Saatavilla http://urn.fi/urn:nbn:fi:lb-2017021505, luettu 25.3.2017.

Suomen kognitiivista kielioppia sukukielten kehyksessä -tutkimusprojekti, Helsingin yliopisto, suomen kielen, suomalais-ugrilaisten ja pohjoismaisten kielten ja kirjallisuuksien laitos (2014). HS.fi-uutiskommenttiaineisto [tekstikorpus]. Kielipankki. Saatavilla http://urn.fi/urn:nbn:fi:lb-2014052718, luettu 20.10.2015.

\section{Kirjallisuus}

732/2015 = Laki oikeudenkäymiskaaren muuttamisesta. http://www.finlex.fi/fi/laki/alkup/2015/ 20150732, luettu 6.7.2016.

Auer, Peter 2005: Projection in interaction and projection in grammar. Text 25(1), 7-36.

Brinton, Laurel J. - Traugott, Elisabeth Closs 2005: Lexicalization and Language Change. Research Surveys in Linguistics. Cambridge University Press, Cambridge.

Bybee, JoAn 2010: Language, Usage, and Cognition. Cambridge University Press, Cambridge.

Croft, William - Cruse, D. Alan 2004: Cognitive Linguistics. Cambridge Textbooks in Linguistics. Cambridge University Press, Cambridge.

Cruse, Alan D. 1986: Lexical Semantics. Cambridge Textbook in Linguistics. Cambridge University Press, Cambridge.

1995: Polysemy and related phenomena from a cognitive linguistic viewpoint. Patrick SaINTDizier ja Evelyn Viegas (toim.): Computational lexical semantics, 33-49. Cambridge University Press, Cambridge.

2000: Meaning in Language: An introduction to Semantics and Pragmatics. Oxford University Press, Oxford.

Dunning, Ted 1993: Accurate Methods for the Statistics of Surprise and Coincidence. Computational Linguistics 19, 61-74.

Evans, Vyvyan 2009: How Words Mean: Lexical Concepts, Cognitive Models, and Meaning Construction. Oxford University Press, Oxford.

Forsman, JAN 2012: Descartesin epäilyn metodi. Pro gradu -tutkielma. Tampereen yliopisto.

GeEraerts, DirK 2006 [1988]: Where does prototypicality come from? Dirk GeEraerTs (toim.): Words and Other Wonders: Papers on Lexical and Semantic Topics, 27-47. Mouton De Gruyter, Berlin.

Hakulinen, Auli - Karlsson, Fred 1979: Nykysuomen lauseoppia. Suomalaisen Kirjallisuuden Seura, Helsinki.

HE 46/2014 = Hallituksen esitys eduskunnalle oikeudenkäymiskaaren 17 luvun ja siihen liittyvän todistelua yleisissä tuomioistuimissa koskevan lainsäädännön uudistamiseksi. https://www.finlex.fi/ fi/esitykset/he/2014/20140046, luettu 6.7.2016.

IVASKA, ILMARI 2015: Edistyneen oppijansuomen konstruktiopiirteitä korpusvetoisesti: avainrakenneanalyysi. Turun yliopiston julkaisuja C 409.

JANTUNEN, JARMO HARRI 2004: Synonymia ja käännössuomi. Korpusnäkökulma samamerkityksisyyden kontekstuaalisuuteen ja käännöskielen leksikaalisiin erityispiirteisiin. Joensuun yliopiston humanistisia julkaisuja 35 .

KANGaSmAA-MinN, EEvA 1983: Derivaatiokielioppia 2: verbikantaiset nominijohdokset. Sananjalka 25, 23-42.

Kilgarriff, AdAm 1997: I don't believe in word senses. Computers and the Humanities 31, 91-113.

KJellmer, Göran 1993: Multiple Meaning and Interpretation: The Case of Sanction. Zeitschrift für Anglistik und Amerikanistik 41, 115-123.

2007: On the Awkward Polysemy of the Verb risk. Nordic Journal of English Studies vol. 6, no. 1.

Koski, MAUno 1981: Mitä leksikaalistuminen on? Sananmuodostuksen ongelmia: seminaari Seilissä 3.- 
4.9.1981. SKYJ 7, 5-27. SKY, Turku.

KS = Kielitoimiston sanakirja 1-3. Kolmas, uudistettu painos. Kotimaisten kielten keskus 2012, Helsinki. KönÖnen, Perttu 2006: Tuomitsemiskynnyksestä rikosasiassa. Juha Lappalainen ja Timo Ojala (toim.): Kirjoituksia todistusoikeudesta, 87-98. Helsingin hovioikeus.

LAmbrecht, KnUt 1994: Information and sentence form. Topic, focus, and the mental representations of the discourse referents. Cambridge University Press, Cambridge.

Langacker, Ronald W. 1987a: Foundations of Cognitive Grammar. Vol. 1. Theoretical Prerequisites. Stanford University Press, Stanford.

1987b: Nouns and Verbs. Language 63, 53-94.

1999: Grammar and Conceptualization. Cognitive Linguistics Research 14. Mouton de Gruyter, Berlin.

2008: Cognitive Grammar - A Basic Introduction. Oxford University Press, Oxford.

LarjavaAra, Matti 2007: Pragmasemantiikka. Suomalaisen Kirjallisuuden Seura, Helsinki.

Leino, Pentti 1991: Lauseet ja tilanteet. Suomen objektin ongelmia. Suomalaisen Kirjallisuuden Seura, Helsinki.

—_ 1993: Suomen kognitivista kielioppia 1: Polysemia - kielen moniselitteisyys. Helsingin yliopiston suomen kielen laitos.

Lyons, John 1977: Semantics 1-2. Cambridge University Press, Cambridge.

Miestamo, Matti 2004: Suomen kieltoverbikonstruktio typologisessa valossa. Virittäjä 108, 364-388.

MÄKISAlO, JukKa 2009: Kielentutkimuksen kvantitatiivisia menetelmiä. Kieli- ja käännöstieteen opetusmonisteita, 2. Joensuun yliopisto.

Möttönen, Tapani 2016: Construal in expression. An Intersubjective Approach to Cognitive Grammar. Helsingin yliopisto.

NiEMI, JARKко 2015: Myönnyttelyn käytänteitä: erimielisyys ja yhteisymmärryksen rakentaminen vuorovaikutuksessa. Helsingin yliopisto.

Nummila, Kirsi-Maria 2011: Tekijännimet Mikael Agricolan teosten kielessä. Henkilötarkoitteisten johdosten merkitykset, funktiot ja rakenteet. Turun yliopisto.

Nuutinen, Olavi 1976: Suomen teonnimirakenteista. Stockholm studies in Finnish language and literature. Tukholman yliopisto.

OnıkкI, Tiına 2000: Mistä mieli merkityksen tutkimukseen? Kognitiivisen kielentutkimuksen merkitysnäkemyksestä. Anu Airola, Heikni J. Koskinen ja Veera Mustonen (toim.): Merkillinen merkitys, 85-114. Gaudeamus, Helsinki.

PäIvı̈, PIA 2007: Suomen kielen asti ja saakka. Terminatiivisten partikkelien synonymia, merkitys, käyttö ja kehitys sekä asema kieliopissa. Turun yliopisto.

RAukko, Jarno 1997: The Status of Polysemy in Linguistics: From Discrete Meanings to Default Flexibility. SKY Journal 10, 145-170.

Salminen, Jutta 2017a: Mitä tarkoittaa epäillä? Epäillä-verbin polaarisesta merkitysvariaatiosta nykysuomessa. Virittäjä 121, 4-36.

2017b: Epäillä-verbin polaarinen kaksihahmotteisuus merkitysmuutoksena. Virittäjä 121, 3766.

Schank, Roger C. - Abelson, Robert P. 1977: Scripts, plans, goals, and understanding. Lawrence Erlbaum Associates, Hillsdale N. J.

SSA = Suomen sanojen alkuperä. Etymologinen sanakirja. I-III. 1992-200o. Suomalaisen Kirjallisuuden Seura ja Kotimaisten kielten tutkimuskeskus, Helsinki.

Stanojević, Maja 2009: Cognitive synonymy: a general overview. Linguistics and Literature 7, 193-200.

Tola, Joonatan 2015: Vaikka vaimo vaatisi eroa. ero-kantaisen johdospesyeen määrällinen tutkimus. Pro gradu -tutkielma. Helsingin yliopiston suomen kielen, suomalais-ugrilaisten ja pohjoismaisten kielten ja kirjallisuuksien laitos.

Tottie, GunNel 1991: Negation in English speech and writing. Quantitative analysis on linguistic structure, 4. Academic Press, San Diego.

Tuggy, David 2006 [1993]: Schematic network: Ambiguity, polysemy, and vagueness. Dirk GeEraerts (toim.): Cognitive linguistics: Basic readings, 167-184. Mouton de Gruyter, Berlin. 
TYysteri, LAURA 2015: Aamiaiskahvilasta ötökkätarjontaan. Suomen kirjoitetun yleiskielen morfosyntaktisten yhdyssanarakenteiden produktiivisuus. Turun yliopiston julkaisuja C 408.

VAN DER WURFF, WIM 1998: On expletive negation with adversative predicates in the history of English. Ingrid Tieken-Boon van Ostade, Gunnel Tottie ja Wim van der Wurff (toim.): Negation in the History of English, 295-328. Mouton de Gruyter, Berlin.

VAINIKKA, ANNE 1992: Kieliopillisten sijojen syntaktinen kuvaus. Virittäjä 96, 295-322.

Verhagen, Arie 2005: Constructions of intersubjectivity. Discourse, syntax, and cognition. Oxford University Press, Oxford.

VILKUnA, MARIA 1989: Free word order in Finnish. Its syntax and discourse functions. SKST 500. Suomalaisen Kirjallisuuden Seura, Helsinki.

Visk 2004 = Hakulinen, Auli - Vilkuna, Maria - Korhonen, Riitta - Koivisto, Vesa - Heinonen, TARJa-Rittta - Alho, Irja: Iso suomen kielioppi. Suomalaisen Kirjallisuuden Seura, Helsinki. Verkkoversio: http://scripta.kotus.fi/visk

Yli-VAKKURI, VALMA 1986: Suomen kieliopillisten muotojen toissijainen käyttö. Turun yliopisto.

\section{JUtTa SALMINEN: Epäily or epäilys? Shared polysemy and specialised typical uses}

The present paper compares the usage patterns of two deverbal nouns of the same root, epäily and epäilys ('suspicion, doubt'). The starting point of the study is the notion that both nouns have inherited polar ambiguity from the verb epäillä 'to suspect, to doubt' without an obvious specialisation to either of the two polar inclinations.

The comparison of these lexemes draws from the HS.fi News Comment Corpus (8.05 million tokens), which includes local Finnish news from the Helsingin Sanomat website and its comments between 5 September 2011 and 4 September 2012. The data contain 603 occurrences of epäily and 173 of epäilys. The difference in frequency reflects the default status of epäily when discussing suspicion of crime, as this topic recurs in local Finnish news.

Contextually varying profiles of these deverbal nouns are investigated to illustrate their relation to the meaning of the root verb and to provide a background for the analysis of polar ambiguity. It is shown that due to different co-textual clues, epäily $(s)$ may profile the nominalised process denoted by the root verb, the proposition considered to be likely (a suspicion), or an institutionalised case (esp. suspicion of crime). However, the borders of the profile categories are not clear-cut.

The polar ambiguity of these nouns is based on the twofold function potential of the possible adjunct of the nouns: it may explicate the content of epäily(s), or function as a target of the doubt that is expressed with epäily(s). A content adjunct is interpreted as likely/possibly true (affirmation-inclining interpretation) and a target adjunct likely/possibly untrue (negation-inclining). Of the three introduced above, the verb-like noun profile is the most fitting to the negation-inclining interpretation with a target adjunct, while the proposition and case profiles are linked to the content of epäily(s) (the proposition regarded as possible/likely). The super schema of evaluative negativity unites the two contrary meanings, and when an expression has no clear polar inclination, this negative tone still remains.

Altogether, the data show the following tendencies for the two lexemes. Mainly, due to the established status of epäily in the context of crime, proposition and case profiles, which connect to affirmation-inclining interpretation polarity-wise, tend to be expressed by this variant. In contrast, the polar inclination of epäilys varies more, and, as a whole, this lexeme attracts more negation both in its complements (epäilys ettei 'suspicion/doubt that not') and scoping over epäilys itself (ei epäilystä(kään) 'no doubt'). The tendencies are shown to be the strongest under the scope of negation. 
Jutta Salminen jutta.salminen@helsinki.fi Suomen kielen, suomalais-ugrilaisten ja pohjoismaisten kielten ja kirjallisuuksien laitos 00014 Helsingin yliopisto

Institut für Fennistik und Skandinavistik Universität Greifswald Hans-Fallada-Str. 20, 17487 Greifswald, Saksa

\section{Liite}

Korkeimman log-uskottavuusosamäärän (LLR) etukollokaatit yhden sanan etäisyydellä. Kohdesanat, joiden frekvenssi on 1, on poistettu taulukoista.

\begin{tabular}{|c|c|c|c|c|c|}
\hline & $\begin{array}{l}\text { etukotekstin } \\
\text { kohdesana }\end{array}$ & LLR & $\begin{array}{r}\text { kollokaation } \\
\text { frekvenssi }\end{array}$ & $\begin{array}{r}\text { noodin } \\
\text { (epäily) } \\
\text { frekvenssi }\end{array}$ & $\begin{array}{r}\text { kohdesanan } \\
\text { frekvenssi }\end{array}$ \\
\hline \multirow[t]{10}{*}{ epäily: } & pelkkä & 149,78 & 20 & 603 & 2394 \\
\hline & kiistää & 92,44 & 10 & 603 & 494 \\
\hline & vahva & 77,05 & 10 & 603 & 1065 \\
\hline & liittyä & 71,89 & 13 & 603 & 4170 \\
\hline & kohdistua & 68,53 & 9 & 603 & 1002 \\
\hline & uusi & 48,45 & 12 & 603 & 8332 \\
\hline & ilmoittaa & 47,75 & 8 & 603 & 2044 \\
\hline & esittää & 36,05 & 7 & 603 & 2715 \\
\hline & perustella & 34,39 & 6 & 603 & 1727 \\
\hline & tyrmätä & 30,37 & 2 & 603 & 6 \\
\hline \multirow[t]{10}{*}{ epäilys: } & herätä & 351,86 & 27 & 173 & 757 \\
\hline & pieni & 54,47 & 9 & 173 & 7818 \\
\hline & herättää & 37,72 & 4 & 173 & 625 \\
\hline & vahva & 33,47 & 4 & 173 & 1065 \\
\hline & hälventää & 30,96 & 2 & 173 & 16 \\
\hline & vahvistaa & 26,11 & 3 & 173 & 673 \\
\hline & mikään & 18,96 & 6 & 173 & 23364 \\
\hline & pelkkä & 18,56 & 3 & 173 & 2394 \\
\hline & olla & 18,43 & 24 & 173 & 419977 \\
\hline & heittää & 14,14 & 2 & 173 & 1016 \\
\hline
\end{tabular}


JUSSI LEHTONEN

\section{Avustajaeläinten ja ikäihmisten yhteinen tulevaisuus \\ Vaihtoehtoisia tulevaisuuksia rakentamassa}

\section{Johdanto}

Artikkelini tavoitteena on analysoida ikäihmisille suunnatun avustajaeläintoiminnan yksilötason vaihtoehtoisia tulevaisuuskuvia ja niiden muodostamista. Tämä tapahtuu kansatieteen ja tulevaisuudentutkimuksen näkökulmat yhdistäen siten, että huomion kohteena ovat ikäihmisten ja avustajaeläinten yhteistä elämää 2040-luvulla käsittelevät tulevaisuuskuvat. Osoitan yhden mahdollisen tavan, jolla mainittujen kahden tieteenalan näkökulmien yhdistäminen onnistuu. Keskiöön nostan tulevaisuudentutkimuksellisen FARtaulukon (ks. taulukko 1 s. 249). Tulen perustelemaan kuuden tulevaisuustaulukkoon sisällytetyn muuttujan valintaa sekä sen, miten muuttujien arvot ovat perusteltavissa. Lopuksi hahmottelen tulevaisuustaulukon pohjalta kolme ikäihmisten ja avustajaeläinten vaihtoehtoista tulevaisuuskuvaa 2040-luvulle. Artikkelin pohjana on kansatieteen alalla uusi suuntaus, kansatieteellinen tulevaisuudentutkimus, joka on samalla soveltavaa kansatiedettä. Aluksi esittelen tämän lähestymistavan sekä käyttämäni tutkimusaineistot ja -menetelmät. Lisäksi avaan tarkemmin FAR-tulevaisuustaulukon rakentamista.

Artikkelin ajallinen horisontti yltää 2040-luvulle asti. Tulevaisuudentutkimuksen tieteenalalla liian lyhyt aika kohti tulevaisuutta rajoittaa toimia, joita voidaan tehdä tavoiteltavan tulevaisuuden saavuttamiseksi tai huonoksi koetun tulevaisuuden välttämiseksi. Jos aikajana on liian pitkälle tulevaisuuteen, yksittäinen ihminen ei välttämättä koe tulevaisuuksia henkilökohtaisesti merkityksellisiksi tai organisaatio omaan olemassaoloonsa vaikuttaviksi. Näin voi tapahtua siitä huolimatta, että käsiteltävä asia voi nykyhetkessä liittyä kiinteästikin ihmisen tai organisaation omaan arkielämään ja sen muuttumiseen. Tällöin johonkin tulevaisuuteen aktiivisesti pyrkiminen saattaa jäädä vähäiseksi, koska asia on abstrakti eikä siihen muodostu riittävän vahvaa henkilökohtaista vuorovaikutussuhdetta. Samassa tilanteessa ollaan myös silloin, kun kaukaisemman tulevaisuuden monenlaiset muutosvoimat eivät näy selkeinä kokonaisuuksina omassa ajassamme tulevaisuuden mennessä liian kauas eteenpäin ja muuttuessa vaikeasti hahmotettavaksi. 
Tämä vaikeuttaa asioiden ennakointia ja vaihtoehtoisten tulevaisuuksien toteutumismuotojen hahmottamista. (Lehtonen 2016, 41-42; Niiniluoto 2013, 24 ja seuraavat; ks. myös Heinonen-Ruotsalainen 2012, 70.)

Tulevaisuudentutkimuksen menetelmien ja näkökulmien yhdistäminen kansatieteelliseen tutkimukseen on uutta, vaikka kansatieteen tulevaisuusorientaatio onkin selvästi vahvistunut 2010-lukua lähestyttäessä. Tulevaisuudentutkimuksessa taas monien tieteenalojen erilaiset yhdistelmät ovat tutkimuksenteon arkea. (Ks. Lehtonen 2016, 19-20, 289; Siivonen 2008, 148.) Tämän vuoksi on tarpeen lyhyesti esitellä kansatieteen ja tulevaisuudentutkimuksen yhdistämistä nimenomaan kansatieteen näkökulmasta käsin. Lähtökohtaisesti molemmat tieteenalat hyödyntävät muiden tieteenalojen näkökulmia ja aineistoja.

Tulevaisuudentutkimuksen tieteenalan yhtenä tarkoituksena on erilaisia menetelmiä ja aineistoja käyttäen hahmotella vaihtoehtoisia tulevaisuuksia. Esimerkiksi omassa tutkimuksessani rakennan tässä artikkelissa tulevaisuuskuvia: millaisina toimintamalleina, tapoina ja näkökulmina ikäihmisen ja hänen avustajaeläimensä tulevaisuus saattaa lähteistäni nousevien tietojen perusteella näyttäytyä? Käytän soveltavan kansatieteen lähestymistapaa, eli tutkimukseni antaa konkreettisia ratkaisumalleja ikäihmisten ja avustajaeläinten yhteiselon järjestämiselle. Näitä malleja esittelen tulevaisuuskuvien muodossa tämän artikkelin tuloksena. Tulevaisuudentutkimuksen tarkoitus ei siis ole selvittää yhtä varmaa ja toteutuvaa tulevaisuutta vaan osoittaa vaihtoehtoja, joiden joukosta jokin toimija - esimerkiksi yhteiskunta, organisaatio tai yksilö - voi löytää tavoiteltavan tai vältettävän tulevaisuuden. Se, mitä tulevaisuutta kulloinkin pidetään hyvänä ja tavoittelemisen arvoisena, riippuu organisaation, yhteiskunnan ja yksilön arvoista ja niiden muuttumisesta tulevaisuudessa. (Kamppinen-Malaska-Kuusi 2003, 26-29; Rubin 2003, 902-903; ks. myös Avustajaeläimet.)

Kansatiede oli tieteenalana pitkään lähinnä historiallista kansankulttuuria tutkiva tiede, jonka aikataso oli menneisyydessä. Suomessa nykyhetken tutkimus alkoi vakiinnuttaa asemaansa yhä vahvemmin erityisesti 1980-luvulta alkaen. (Löfgren 1996, 81; Sääskilahti 1997, 91-92.) Turun yliopiston kansatieteen oppiaineessa tutkimuskohteet ovat olleet myös omaan aikaamme linkittyneitä keskittyen erityisesti murroskausiin sekä erilaisiin ilmiöihin, tapahtumiin ja käytänteisiin ihmisten arjessa. Historiallisen ja nykyhetkeen liittyvän tutkimusperinteen jatkoksi kansatieteellinen tulevaisuudentutkimus antaa mahdollisuuden ihmisryhmän tai yksittäisenkin ihmisen vaihtoehtoisten tulevaisuuksien suunnitteluun ja niiden tavoittelemiseen osana jokapäiväistä arkielämää. Tulevaisuus, joka rakentuu historian ja nykyhetken päälle, on luonteva tutkimuskohde myös kansatieteelle.

Tulevaisuudentutkimus on tieteenalana nuorempi kuin kansatiede, jonka juuret ovat 1800-luvulla. Maailmalla oli jo 1900-luvun alkupuolelta alkaen pyrkimystä tieteellisen tulevaisuudentutkimuksen vakiinnuttamiseksi. Eräs virstanpylväs saavutettiin 1940luvun jälkeen, jolloin yhdysvaltalainen RAND-yhtiö laajensi toimintaansa ei-sotilaallisiin tulevaisuusselvityksiin. (Bell 2003, 29; Borg 2013, 50-52; Söderlund-Kuusi 2003, 262-264.) Tulevaisuudentutkimus alkoi muuttua laaja-alaisten teemojen kautta tieteeksi, joka vaikuttaa monella tasolla yhteiskuntaan ja sen toimijoihin sekä tarjoaa työkaluja 